OPEN ACCESS

Edited by:

Edit I. Buzás,

Semmelweis University, Hungary

Reviewed by:

Kerstin Nundel,

University of Massachusetts Medical

School, United States

Johan Rönnelid,

Uppsala University, Sweden

*Correspondence:

Chetna Son

Chetna.Soni@nyulangone.org

Boris Reizis

Boris.Reizis@nyulangone.org

Specialty section:

This article was submitted to Autoimmune and Autoinflammatory

Disorders,

a section of the journal

Frontiers in Immunology

Received: 21 December 2018 Accepted: 26 June 2019

Published: 10 July 2019

Citation:

Soni $C$ and Reizis B (2019) Self-DNA at the Epicenter of SLE: Immunogenic

Forms, Regulation, and Effects.

Front. Immunol. 10:1601

doi: 10.3389/fimmu.2019.01601

\section{Self-DNA at the Epicenter of SLE: Immunogenic Forms, Regulation, and Effects}

\author{
Chetna Soni ${ }^{1 *}$ and Boris Reizis ${ }^{1,2 *}$ \\ ${ }^{1}$ Department of Pathology, New York University School of Medicine, New York, NY, United States, ${ }^{2}$ Department of Medicine, \\ New York University School of Medicine, New York, NY, United States
}

Self-reactive B cells generated through $V(D) J$ recombination in the bone marrow or through accrual of random mutations in secondary lymphoid tissues are mostly purged or edited to prevent autoimmunity. Yet, $10-20 \%$ of all mature naïve B cells in healthy individuals have self-reactive B cell receptors (BCRs). In patients with serologically active systemic lupus erythematosus (SLE) the percentage increases up to 50\%, with significant self-DNA reactivity that correlates with disease severity. Endogenous or self-DNA has emerged as a potent antigen in several autoimmune disorders, particularly in SLE. However, the mechanism(s) regulating or preventing anti-DNA antibody production remain elusive. It is likely that in healthy subjects, DNA-reactive B cells avoid activation due to the unavailability of endogenous DNA, which is efficiently degraded through efferocytosis and various DNA-processing proteins. Genetic defects, physiological, and/or pathological conditions can override these protective checkpoints, leading to autoimmunity. Plausibly, increased availability of immunogenic self-DNA may be the key initiating event in the loss of tolerance of otherwise quiescent DNAreactive $B$ cells. Indeed, mutations impairing apoptotic cell clearance pathways and nucleic acid metabolism-associated genes like DNases, RNases, and their sensors are known to cause autoimmune disorders including SLE. Here we review the literature supporting the idea that increased availability of DNA as an immunogen or adjuvant, or both, may cause the production of pathogenic anti-DNA antibodies and subsequent manifestations of clinical disease such as SLE. We discuss the main cellular players involved in anti-DNA responses; the physical forms and sources of immunogenic DNA in autoimmunity; the DNA-protein complexes that render DNA immunogenic; the regulation of DNA availability by intracellular and extracellular DNases and the autoimmune pathologies associated with their dysfunction; the cytosolic and endosomal sensors of immunogenic DNA; and the cytokines such as interferons that drive autoinflammatory and autoimmune pathways leading to clinical disease. We propose that prevention of DNA availability by aiding extracellular DNase activity could be a viable therapeutic modality in controlling SLE.

Keywords: DNases, systemic lupus erythematosus, toll-like receptors, interferons, autoantibodies 


\section{INTRODUCTION}

\section{Anti-DNA Antibodies as a Biomarker for SLE}

Anti-DNA antibodies (Abs) are not exclusive to systemic lupus erythematosus (SLE or lupus), yet, their persistence in serum is the most reliable serological marker for lupus diagnosis (1-4). High titers of anti-DNA Abs directly correlate with disease activity $(3,5)$, predictions of lupus flares $(6,7)$, hypocomplementemia (8), and proliferative lupus nephritis (9, 10). $70-80 \%$ of SLE patients have detectable levels of anti-DNA Abs, of which $\sim 45-50 \%$ have high titers $(3,8,11)$. This is in contrast with anti-DNA Ab- positive non-SLE patients with rheumatoid arthritis (RA), scleroderma, vasculitis, tuberculosis, autoimmune hepatitis, viral hepatitis or cancer, where the titers are predominantly low-to-moderate $(3,8)$. Additionally, a fraction of aged healthy individuals also have anti-DNA Abs but rarely at high titers (12). The correlation of high titers of antiDNA Abs with SLE disease severity is indicative of a requirement for the persistent availability of DNA as an immunogen. Additionally, many pathological conditions including infections, and cancer can induce anti-DNA Abs which invokes a status for DNA as a readily available adjuvant associated with various proteins under different conditions.

\section{B Cells in Anti-DNA Responses}

Rheumatic diseases like SLE, RA, Sjogren's syndrome, vasculitis, antiphospholipid syndrome etc., which cause development of anti-DNA Abs in several patients, are driven by $\mathrm{B}$ cells $(13,14)$. Moreover, DNA-specific B cells can readily expand in all individuals upon exposure to microbial DNA (4). In healthy individuals, the microbial DNA-specific B cell expansion is transient. However, under autoimmune conditions, the bacterial DNA-reactive B cells also recognize self-DNA and are retained after the infection is cleared (15). It is therefore of clinical relevance to understand the conditions which cause the persistence of DNA-reactive B cells in autoimmune diseases like SLE. Toward this goal, significant advances have been made in the area of $\mathrm{B}$ cell biology to understand the regulation of autoreactive B cells. A recent comprehensive review on $B$ cell genetic risk factors involved in SLE highlighted the importance of examining specific B cell subsets for better targeted therapeutic intervention (16). The major B cells subsets implicated in anti-DNA antibody production include germinal center (GC) B cells that produce long-lived plasma/ memory cells and the extrafollicularly generated short-lived plasmablasts $(17,18)$. Several studies in mice outline a significant role of the extrafollicular pathway in anti-DNA/ chromatin $\mathrm{Ab}$ production, showing that $\mathrm{B}$ cells can undergo both isotype switching and affinity maturation outside of the GCs (19-22). Notably, expansion of extrafollicular B cells in active human SLE patients has also been reported $(23,24)$. In a recent study, specific subsets of B cells involved in the extrafollicular pathway of autoantibody production in SLE were defined in patients with active disease (25). Unlike the GC pathway, the absence of extrafollicular tolerance checkpoints might explain the preferential emergence and amplification of anti-DNA responses via the extrafollicular route.

In accordance with the predominantly short-lived nature of DNA-reactive B cells, B cell targeting therapies like Rituximab (anti-CD20) and Belimumab (anti-BAFF) have been partially effective in SLE treatment $(13,14,26)$. There was a modest yet significant reduction of SLE disease severity in patients with serologically and clinically active SLE upon treatment with Belimumab (Benlysta), alongside standard therapy (7, 2729). Notable observations from phase III Belimumab trials BLISS-52 and BLISS-76 $(30,31)$ were that increased antiDNA Ab titers predicted lupus flares $(6,7)$, while successful treatment resulted in reduced anti-DNA Abs (29), positively correlating anti-DNA Abs with disease manifestations. Although anti-B cell therapies are promising $(14,32)$, there remains great variability in the reduction of autoantibodies and disease severity upon treatment, in part due to the variable B cell subsets involved in antibody production. Additionally, most patients receive supplemental concurrent administration of corticosteroids that have several adverse side effects, including infections, hypertension, hyperglycemia, osteoporosis, cataracts, glaucoma, and cognitive impairment $(33,34)$. Therefore, effective treatment of SLE with minimal side effects requires newer approaches and interventions in addition to and beyond B celltargeted therapy.

\section{T Cells in Anti-DNA Responses}

Along with $\mathrm{B}$ cells, the generation, and amplification of anti-DNA antibodies requires a $\mathrm{T}$-cell dependent antigenic stimulation process, which indicates that anti-DNA antibody production is not just a consequence of polyclonal stimulation of immune cells. Indeed, autoreactive $\mathrm{T}$ cell clones have been identified in mice (35) and humans (36-38) and are essential for the amplification of autoreactive B cells (Figure 1). A subset of $\mathrm{CD}^{+} \mathrm{T}$ cells expressing high CXCR5, ICOS, and PD-1, named follicular helper T cells (Tfh) are particularly implicated in several autoimmune diseases. Tfh promote the generation of germinal center-driven anti-DNA Abs in several lupus mouse models by providing key cytokines like IL-21 and IL-4 to B cells in the germinal centers (39-41). Likewise, a subset of SLE patients have increased numbers of $\mathrm{CD} 4^{+}$CXCR5 ${ }^{+}$ICOS ${ }^{\text {hi }} \mathrm{PD}$ - $1^{\text {hi }}$ circulating $\mathrm{T}$ cells, resembling mouse Tfh cells $(39,42,43)$. Another distinct population of helper $\mathrm{T}$ cells has also been identified in the generation and amplification of anti-DNA/ chromatin responses through the extrafollicular pathway in mice (44-46), and more recently in SLE patients (47). Given the pleiotropic roles of T cells as B cell helpers (Tfh), cytokine producers (Th1, Th17) and suppressors of autoimmunity (Tregs) in SLE, it is no surprise that several T-cell targeted therapies are in use and/ or under investigation for lupus (48).

\section{pDCs in Anti-DNA Responses}

In addition to the direct role of $\mathrm{B}$ and $\mathrm{T}$ cells in anti-DNA $\mathrm{Ab}$ production, high serum type-I interferon levels and activity directly correlate with high anti-DNA Ab titers in SLE patients (49-51). Plasmacytoid dendritic cells (pDCs) are considered as professional IFN-I producing cells and are implicated in 


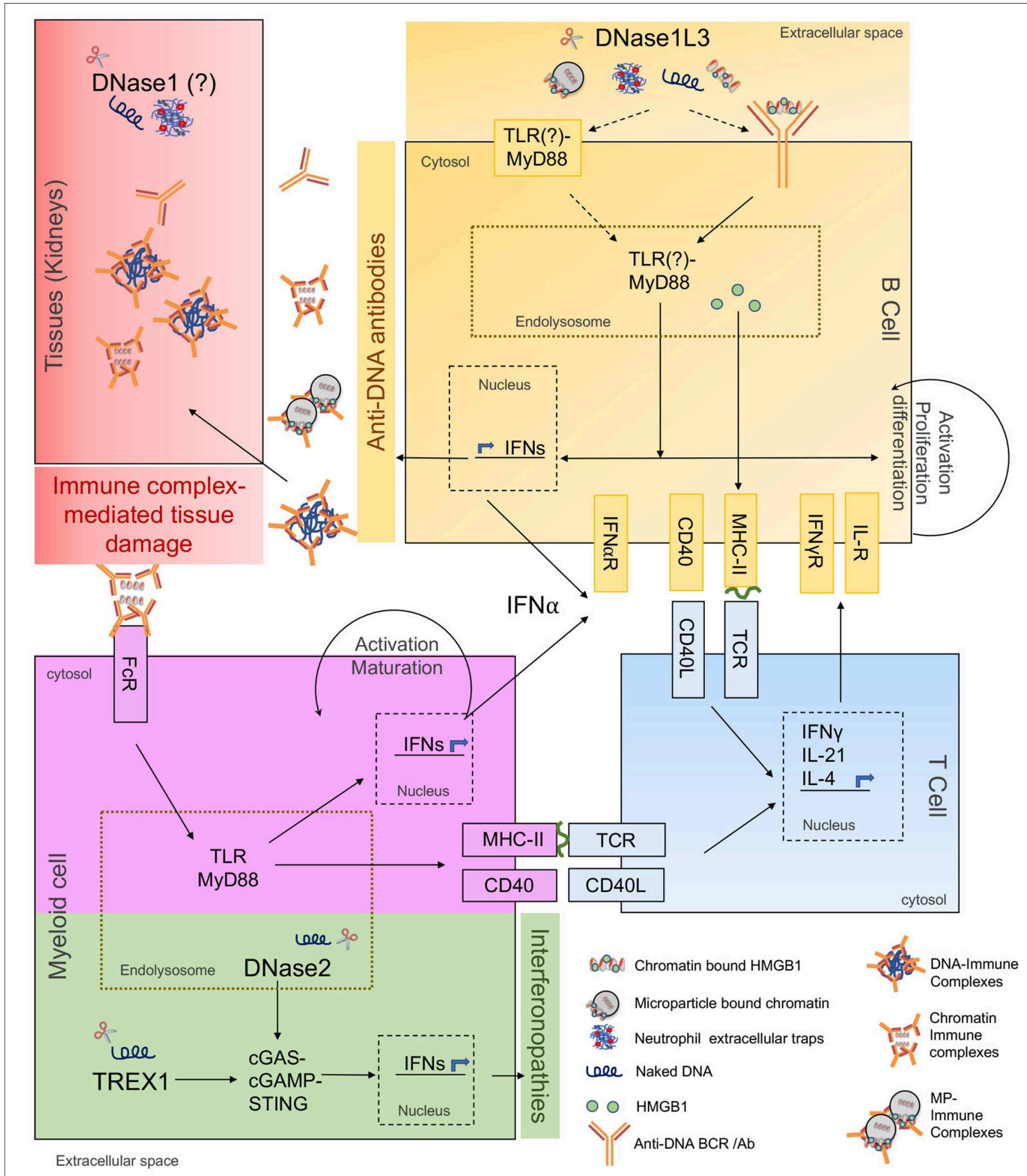

FIGURE 1 | Cellular and molecular responses to extracellular and intracellular DNA. The schematic shows involvement of extracellular DNases in anti-DNA responses/ SLE pathogenesis and intracellular DNases in interferonopathies. The major molecular pathways of autoantibody and autoinflammatory responses are highlighted in different colors as described below. Yellow: Primary cellular and molecular pathways of anti-DNA Ab production. DNase1L3-deficiency increases availability and uptake of cfDNA (naked DNA, NET-DNA, cell-free chromatin, and microparticle-associated chromatin), along with associated proteins potentially through self-reactive BCRs or through cell-surface TLRs. Internalized self-DNA causes TLR-MyD88 dependent B cell activation, differentiation, IFN production, and presentation of 
FIGURE 1 | cfDNA-associated peptides to T cells. Blue: T cells help in anti-DNA Ab production. Costimulatory and cognate MHC-TCR interactions between DNA-reactive $B$ and T cells stimulate activation, proliferation, and differentiation of B cells into anti-DNA Ab secreting cells. Purple: Amplification of anti-DNA Abs through myeloid cell help. Anti-DNA antibodies accumulate and form immune complexes with cfDNA which are internalized through Fc-receptors on myeloid cells i.e., DCs, pDCs, macrophages, further inducing IFN production through TLR-MyD88 pathway. Myeloid cells also present self-antigen to T cells further amplifying the B-T cell interaction loop and anti-DNA Ab production. Red: Undigested DNA promotes IC formation and deposition in target organs. DNase1 expressed in kidneys digests locally produced apoptotic cell-derived DNA. IC-formation is enhanced in the presence of extracellular DNA. ICs deposit in kidneys causing immune complex-mediated tissue damage. Green: DNases and signaling pathways regulating interferonopathies. DNase2 cleaves endocytosed apoptotic cell-derived DNA while TREX1 cleaves cytosolic DNA. Absence of DNase2 and TREX1 trigger activation of cGAS-STING pathway causing IFN production leading to interferonopathies. DNase2 and TREX1 do not directly contribute to anti-DNA antibody production.

autoimmunity (52, 53). Stage III-IV lupus nephritis (LN) patients also show increased infiltration of pDCs in kidneys (54). Consistently, pDC depletion in BXSB and B6. Nba2 models of SLE ameliorated disease $(55,56)$. Furthermore, functional impairment of pDCs by monoallelic deletion of Tcf4 was sufficient to reduce autoantibody production and disease manifestations in two genetic mouse models (57). Clearly, the role of pDCs in autoimmunity is evident but their precise role in anti-DNA antibody production needs further investigation. In humans, $\mathrm{pDCs}$ were shown to promote $\mathrm{B}$ cell differentiation into plasmablasts/ plasma cells by producing IFN $\alpha$ and IL6 in vitro (58), while activated human B cells were able to induce IFN $\alpha$ production by pDCs (59). In another study, pDCs from healthy subjects promoted the expansion of IL10 producing regulatory $B$ cells through IFN $\alpha$, while pDCs from SLE patients did not (60). This evidence for a reciprocal interaction between $\mathrm{B}$ cells and $\mathrm{pDCs}$ with the involvement of IFN $\alpha$, warrants further investigation of the role of pDCs in anti-DNA antibody production.

Taken together, the generation of anti-DNA Abs in SLE requires the activation and interaction of several key immune cell types, depicted in Figure 1. In the following sections we will review what we know so far about the forms of antigenic DNA, its regulation and sensing, and the effector responses that drive anti-DNA Ab production.

\section{Immunogenic DNA: Sources and Protein Partners}

DNA by itself is a weak antigen compared to macromolecules like proteins, lipids, and glycans. However, certain nucleotide sequences and structural determinants can be immunogenic. Anti-DNA Abs to specific bacterial DNA are present in healthy individuals and do not react with other bacterial or endogenous DNA (61). On the other hand, antibodies to bacterial DNA in SLE patients cross react with all DNA irrespective of its source (61-63). Such promiscuity of anti-DNA Abs in SLE patients could be explained through: (1) positive selection of $\mathrm{BCR}$ clones recognizing common determinants of DNA, e.g., phosphodiester backbone due to B cell tolerance checkpoint defects; (2) epigenetic/ structural modification of endogenous DNA through chemical modifications or interactions with DNAbinding proteins; or (3) the excessive availability of immunogenic cell-free DNA (cfDNA) due to clearance or DNA digestion defects. Overall, it is likely that the availability of modified immunogenic DNA to DNA-reactive B cells precipitates SLEassociated pathogenic anti-DNA responses (Figure 1). cfDNA is detectable in the serum and plasma of healthy subjects (64), while its levels increase in conditions associated with excessive cell death, e.g., pulmonary embolism, mechanical, or drug induced injury/ trauma, cancer, pregnancy, sepsis, organ transplantation, RA and SLE $(65,66)$, summarized in Table 1 . The common forms of cell death that cause cfDNA release include apoptosis, necrosis, and NETosis.

\section{Neutrophil Extracellular Traps}

NETosis is a form of neutrophil cell death involving release of neutrophil extracellular traps-NETs (92). NETs are released through a process of nuclear decondensation followed by either slow (lytic) or rapid (non-lytic) release of chromatin studded with neutrophil granular proteins. The complex biology of NETs/ NETosis and its roles in antimicrobial immunity, pathological conditions like allergic asthma, vasculitis, RA, psoriasis, and SLE were recently comprehensively reviewed (74). Increased NETosis was identified in kidney and skin biopsies from SLE patients with lupus nephritis and cutaneous SLE, respectively (93). Moreover, a positive correlation was observed in SLE patients with reduced NET-associated DNA (NET-DNA) degradation and lupus nephritis (94). The pathogenic effects of NETs in psoriasis $(75)$ and $\operatorname{SLE}(76,77)$ have been attributed to their stimulatory activity on $\mathrm{pDCs}$, wherein nucleic acid-mediated TLR9/7 stimulation causes type I IFN secretion, which in turn potentiates the autoinflammatory loop (76-78).

The stimulatory NET components are a composite of neutrophil genomic DNA (gDNA), mitochondrial DNA (mtDNA) and neutrophil granular proteins, which are interferonogenic $(78,83,84)$. Like gDNA MtDNA is associated with DNA-binding proteins to form complexes called nucleoids, akin to chromatin. Transcription factor A-mitochondria (TFAM), is a high-mobility group (HMG) protein involved in the compaction of mitochondrial DNA into nucleoids. Unlike other cells, damaged mtDNA in neutrophils is not degraded through "mitophagy"; instead, damaged-unoxidized mtDNA is decondensed and expelled, while oxidized mtDNA (ox-mtDNA) is degraded through lysosomes within neutrophils or after uptake by macrophages. Both these pathways are non-inflammatory in healthy individuals (95). However, in several SLE patients, due to the blocking effect of anti-RNP Abs or IFNs on TFAM, neutrophil-mtDNA is unable to dissociate from nucleoids, hence ox-mtDNA is retained within the neutrophils and expelled with NETs, which induces the production of type-I IFNs through pDCs (78). Indeed, in about $50 \%$ of SLE patients $(n=14)$ with anti-RNP Abs, ox-mtDNA is present, and so are antibodies to 
TABLE 1 | Autoimmune responses to extracellular DNA-Antigens, regulators, and sensors.

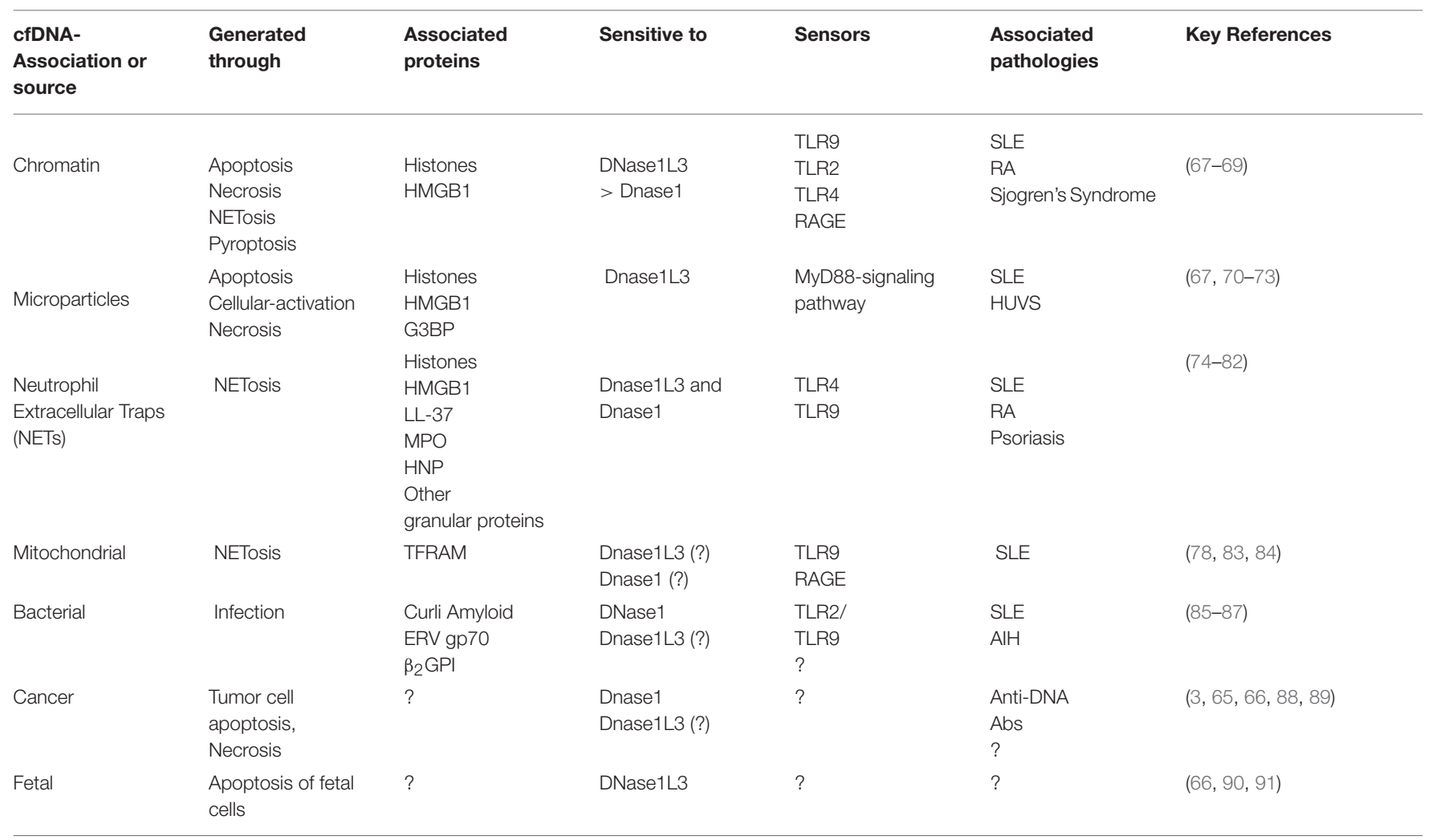

ERV gp70, Endogenous retrovirus glycoprotein 70; HMGB1, High mobility group box 1; G2RB, galectin 3 binding protein; LL-37, cathelicidin-derived antimicrobial peptide; MPO,

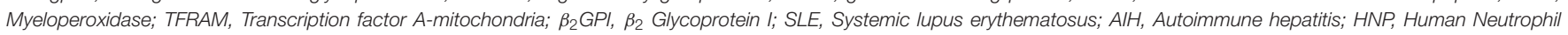
protein; HUVS, Hypocomplementemic urticarial vasculitis syndrome; ?, unknown.

it (78). Increased NETosis $(77,84)$ and increased anti-mtDNA Abs are associated with increased anti-dsDNA, IFN-signature and disease activity index in SLE patients (83), indicating an important role of neutrophil mtDNA in SLE pathogenesis.

Apart from self-DNA and ox-mtDNA, the DNA-associated neutrophil microbial peptides LL37 and human neutrophil proteins (HNPs), human beta-defensin 2 and 3 are strong potentiators of IFN responses. LL-37 cause aggregation of DNA fragments, making them resistant to nucleases and facilitating their endocytosis in pDCs via autoantibody-Fc receptor-mediated uptake and IFN production $(75,77,96)$. In monocytes, LL37 promoted the uptake of self-DNA to activate type I IFN responses through cytosolic DNA sensor cGAS-STING (79). Overall, in different cell types LL37-DNA complexes are potent inducers of type-I IFN through cytosolic or endosomal sensing. Not surprisingly, $40-55 \%$ of SLE patients were also found to develop anti-LL37 and anti-HNP antibodies, which significantly correlated with serum IFN $\alpha$ and disease activity score (77). These data suggest that increased NETosis drives chronic IFN production from $\mathrm{pDCs}$ in SLE patients, via production of high molecular weight immune complexes containing gDNA, ox-mtDNA and LL37. It was recently shown in human SLE patients that LL37-DNA complexes from netting neutrophils promoted internalization of selfDNA resulting in activation of LL37-specific human memory
B Cells via TLR9 stimulation and production of anti-LL37 Abs (80).

In summary, autoimmune responses to NETs studied so far provide evidence for NET-DNA (gDNA/ mtDNA) as a TLR9 ligand and as an adjuvant promoting IFN production and polyclonal proliferation of $\mathrm{B}$ cells, including DNA reactive $\mathrm{B}$ cells in SLE, RA (81), psoriasis etc. However, there is little evidence to suggest that NET-DNA serves as a direct autoantigen for DNAreactive $\mathrm{B}$ cells. Further experiments need to be undertaken to answer these questions.

\section{Intracellular and Apoptotic DNA}

Oxidized mtDNA generated within the cells due to oxidative stress can be immunogenic if not processed and purged efficiently. Autophagic clearance of cytoplasmic substrates in the lysosomes has been suggested to prevent the availability of altered self-antigens including modified nuclear-DNA and ox-mtDNA in the cytosol $(97,98)$. A recent study using monocytes from SLE patients found that autophagic degradation of mtDNA in lysosomes is essential to prevent its accumulation in the cytosol. When accumulated, mtDNA activated the cGAS-STING pathway causing differentiation of monocytes into autoinflammatory DCs (99). Interestingly, IFN $\alpha$ signaling triggered increased mitochondrial respiration, oxidative stress and impaired lysosomal degradation in monocytes, suggesting 
a direct role of IFN $\alpha$ in autoinflammation (99). This study highlights the importance of efficient mitochondrial recycling through autophagy in the maintenance of peripheral tolerance. In addition to mtDNA, apoptotic DNA internalized by phagocytes is also digested within acidified lysosomes. Inefficient lysosomal maturation in macrophages derived from lupus-prone MRL/lpr mice caused increased oxidative stress and impaired acidification of lysosomes. This promoted prolonged accumulation of internalized nucleic acids in endolysosomes and leakage into the cytosol, activating TLRs, and cytosolic sensors (100). Overall, autophagic and lysosomal degradation of self/internalized nucleic acids and associated proteins prevents autoinflammation.

\section{Microparticles}

Apoptotic cells are quickly efferocytosed by macrophages under an anti-inflammatory program, the impairment of which can contribute to SLE (101). Upon cell death, DNA could be exposed extracellularly on apoptotic bodies (102), microparticles (MPs) (70), or as nucleosomes (103). MPs are small lipid membrane bound vesicles of $0.2-1 \mu \mathrm{m}$ in diameter, generated during late apoptosis/ early necrosis of platelets, leukocytes, endothelial cells, or upon cellular activation through TLRs (70). MPs are decorated with different proteins like transporters, adhesion molecules, surface receptors etc., depending on their cellular parent, along with several constitutive proteins like galectin 3 binding protein (G3BP) (71), HMGB1 (104) and histones. MPs also contain nucleic acids like DNA, RNA, and microRNAs which could be surface exposed or encapsulated (105). MPassociated DNA appears concealed from the most abundant extracellular nuclease-DNase1, and specifically requires the activity of DNase1L3 for efficient degradation (67). Due to their ubiquitous production by all cells and unique structural/ antigenic properties, MPs present the most abundant and enduring source of autoantigens including cfDNA.

Although MPs are produced in all individuals and were proposed to have homeostatic functions $(106,107)$, several pathologies are also associated with them. Considerable increase in numbers, alterations in cellular origin and composition of circulating MPs have been implicated in atherosclerosis, thrombosis, vasculitis, systemic sclerosis, diabetes, thrombocytopenia, and rheumatoid arthritis $(72,107-$ 109). MP-associated DNA and proteins have also emerged as important contributors to SLE pathogenesis. Antibodies from SLE patient sera and mouse models, as well as monoclonal antidsDNA Abs, have been shown to bind DNA in microparticles $(67,73,110)$. There is also a significant increase in proportions of MPs in SLE patients with surface bound IgG2, IgM, and C1q, which positively correlates with disease activity, anti-DNA Abs titers and complement activation in patients $(110,111)$. There is also an increase in the concentration/ proportion of circulating MPs in SLE sera with altered protein composition-expressing VCAM-1, CD40L, HMGB1, or G3BP (71, 110, 112), which could serve to further engage ICs. In agreement, MPs-expressing G3BP were found to predominate in SLE patient sera $(n=44)$ (71). Moreover, colocalization of G3BP with IgG was imaged by immune electron microscopy in the glomeruli of nephritic kidneys, suggesting local cell-derived MPs as additional source of autoantigen for tissue IC-deposition (71). Overall, it is likely that circulating ICs form early in lupus development and initially may not reach the threshold of pathogenicity. Their eventual deposition in tissues and the ensuing organ damage could be enhanced by additional local factors such as impaired degradation of DNA. This multistep process may also explain why not all lupus patients develop lupus nephritis.

It was reported that MP-associated ICs from SLE patients promote ROS production in neutrophils and prime them for LPS-mediated NETosis $(113,114)$. MPs derived from SLE patients activated blood-derived $\mathrm{pDCs}$ and monocyte-derived DCs to express increased CD80, CD83, IL-6, and TNF $\alpha$ (113). Notably, unlike SLE-MPs, MPs from controls, RA and systemic sclerosis patients lacked MP-associated chromatin and did not activate DCs, nor induced NETosis (113). This agrees with our observations that about $1 / 3^{\text {rd }}$ of the SLE patients with sporadic SLE, have DNase-sensitive chromatin on the surface of their MPs (67). The loss of DNase1L3 activity causes preferential accumulation of DNA in MPs (67) as well as the presence of higher molecular weight DNA in the plasma (90). These higher order structures are much more capable of engaging multiple BCRs in a stable interaction (4), and therefore could be potent stimulators of B cells with DNA-reactive BCRs. Together these studies are suggestive of a significant role of MP-associated chromatin as an abundant source of self-DNA in SLE, for activation of $\mathrm{pDCs}$ and DCs via the Fc receptors and potentially direct activation of DNA-reactive BCRs.

\section{Microbial (Bacterial/ Viral) DNA}

SLE is a multifactorial disease requiring genetic susceptibility and environmental triggers for complete loss of tolerance and pathogenic manifestations. A major cause of lupus flares and increased disease activity in SLE patients is due to infections (7). Bacterial infections are most common in SLE patients and thought to contribute to SLE pathogenesis by enhancing inflammation and generating cross-reactive $B$ cells which recognize bacterial as well as self-DNA (61). Bacterial amyloid protein-DNA composites were shown to stimulate a potent IFN response and trigger autoantibody production including antidsDNA Abs in lupus-prone as well as wild type mice (115, 116). Infections by all bacterial strains expressing amyloid-DNA complexes could potentially trigger autoimmunity in predisposed individuals, which could contribute to sporadic SLE and also lupus flares.

The role of microbiota in autoimmunity is well-appreciated, although poorly understood (117). A recent study showed that the pathobiont Enterococcus gallinarum was able to translocate to the liver and activate autoantigenic T cells, induce IFN-responses through TLR7 stimulation and anti-dsDNA Ab production in lupus prone mice. Accordingly, the pathological responses could be alleviated by antibiotic treatment (85). In several SLE patients, reactivation of human polyomavirus (BK virus) generates antibodies to T-antigen, DNA and DNA-binding proteins-TBP (TATA-box binding protein) and CREB (cAMP response element binding protein). Specifically, anti-dsDNA Ab were confined to patients with frequent polyomavirus reactivations and expression of $\mathrm{T}$ antigens (86), indicating a role for T-Ag-DNA complexes 
in the stimulation of DNA-reactive B cells. Other potential sources of cfDNA in autoimmunity include tumor-derived DNA in cancer patients and fetal-DNA in pregnant females (66, 91). Altogether, these studies suggest that microbial DNA may promote autoimmune responses including the production of anti-DNA Abs; however, its primary antigenic role in the loss of tolerance to self-DNA has not been firmly established.

\section{DNases as Key Regulators of Immunogenic DNA}

Innate nucleic acid (NA) sensors do not discriminate between foreign and self-NAs, hence the processing or metabolism of endogenous NAs is of paramount importance to prevent immune stimulation. Therefore, it is not surprising that $\sim 40 \%$ of the genes involved in monogenic or Mendelian-inherited forms of autoimmunity are nucleases. Nucleases can be broadly classified into two main categories depending on their spatial expression: (1) Intracellular nucleases-cleave NAs inside the cells, during apoptosis or after uptake of apoptotic bodies. (2) Extracellular nucleases-cleave NAs exposed extracellularly during apoptosis or generated outside of the cells. The tissue expression profile, structure, enzymatic activity, and functions of the two main classes of DNases in various pathological conditions were recently reviewed $(118,119)$.

\section{Intracellular Nucleases: Major Negative Regulators of Autoinflammation Cytosolic Nucleases}

Genetic autosomal recessive mutations in RNA processing enzymes of the RNASEH2 complex, ADAR1, and SAMHD1 cause abnormal induction of type-I IFNs and lead to AicardiGoutières syndrome (AGS) and related interferonopathies. In addition to these RNases, an autosomal recessive mutation in the cytoplasmic-ER membrane-resident $3^{\prime}$-DNA repair exonuclease1 (TREX1 or DNASEIII) also causes AGS and SLE (120, 121). Classical AGS is identified very early in age, mainly as a neuroinflammatory disorder of the central nervous system with very high levels of IFN $\alpha$ in the cerebrospinal fluid. Glaucoma, thrombocytopenia, hepatomegaly, chilblain-like skin lesions, and late onset of SLE like symptoms are also typical of AGS (122). Analysis of serum autoantibodies from 56 AGS patients (23.4\%-TREX1; 57.1\%-RNASEH2B; 2.1\% RNASEH2A; $4.3 \% ; 8.5 \%$ RNASEH2C; $4.3 \%$ SAMHD1; and 4.3\% ADAR1 mutants) was performed, using an autoantibody array to assess their antigen-specificity. The study revealed their specificity to nuclear antigens like gp210, PCNA, Ro/SSA, Sm/RNP, SS-A/SS-B etc. Even though AGS and SLE share several overlapping disease manifestations, ss/dsDNA specific antibodies were not detected in any of the AGS patient sera in this study (123). Moreover, in a previous AGS clinical study, only 3 patients (all $<3$ years age) from a cohort of 24 had anti-dsDNA Abs. Among the three, one patient had a mutation in TREX1, one in RNASEH2C and one had an unknown mutation (124). Trex1 $1^{-/-}$mice do not develop classical AGS, but rather develop lethal inflammatory myocarditis, without anti-chromatin/ DNA Abs $(125,126)$. These studies indicate a limited role for the intracellular exonuclease TREX1 in anti-DNA B cell responses.

\section{Lysosomal DNases}

DNASE2 is an endonuclease that functions in the lysosomes and is known to process DNA internalized with apoptotic cells. DNASE2 is expressed by macrophages in almost all tissues. Mice deficient in DNASE2 die in-utero, due to an overwhelming IFN $\alpha$ response and lethal anemia $(127,128)$. Sequencing analysis on 24 SLE patients from a Korean cohort revealed 6 sequence variants of DNASE2, all of which were at a higher risk for renal disorders but showed no significant association with SLE (129). Recently, three individuals from two families of Algerian or Italian ancestry were identified with biallelic mutations in DNASE2, causing complete loss of DNASE2 endonuclease activity. They were able to survive with medical intervention but had severe neonatal anemia, glomerulonephritis, liver fibrosis, and arthropathy. The hallmark yet again was the excessive production of IFN $\alpha$ and associated interferonopathies (130). Remarkably, all the patients with DNASE2 mutations had high titers of anti-DNA Abs and renal disorders. Further analysis of DNASE2 in SLE patients will shed more light on its role in SLE pathogenesis and antiDNA responses. Notably, both the intracellular DNases-TREX1 and DNASE2, signal through the cGAS-STING pathway for IFN production (131).

Most recently, two endolysosomal proteins phospholipases D3 and D4 (PLD3/PLD4) with putative phospholipase activity were shown to have a functional $5^{\prime}$ exonuclease activity preferentially on unstructured ssDNA. PLD3 or PLD4-deficient mice displayed a TLR9-stimulated inflammatory syndrome while PLD3/4 double-deficient mice were unable to survive beyond the age of 21 days due to severe liver inflammation. Interestingly, the observed autoinflammatory syndrome was mediated by IFN $\gamma$ instead of IFN $\alpha$. Although there was excessive TLR9 activity causing IFN $\gamma$ production, no autoantibody responses were reported (132). Polymorphisms in PDL4 linked to RA and systemic sclerosis $(133,134)$ have also been reported. Altogether, these studies identify the predominant function of intracellular nucleases in preventing autoinflammatory conditions, whereas their contribution toward anti-DNA antibody responses may be limited, as shown in Figure 1.

\section{Extracellular DNases: Negative Regulators of Extracellular Immunogenic DNA DNase1: A Potential Negative Regulator of Lupus Nephritis?}

DNasel is the most abundant secreted endonuclease, that is primarily expressed in the salivary glands, kidneys and gut (135). The association of DNasel with SLE was initially identified through the DNase $1^{-/}$mouse model generated on a mixed B6/129 background, in which some mice developed anti-DNA and anti-nucleosome-Abs (predominant), as well as glomerulonephritis in a gender-independent manner. However, in subsequent studies it was shown that the B6/129 mixed background itself caused most of the observed SLE phenotype (136), as DNase $1^{-/-}$mice on a pure B6 background did not develop SLE features (68). 
Similarly, limited association of DNASE1 with anti-DNA antibody production in human SLE has been identified. Two Japanese patients that developed serological features of SLE with high titers of anti-DNA and anti-Nuc Abs, were identified with an $\mathrm{A} \rightarrow \mathrm{G}$ mutation in exon 2 of human DNASE1 causing a 3-4 fold reduction in enzymatic activity (137). Till date there are no further reports on SLE patients identified with similar or other mutations in DNASE1 (138). However, in another study with 113 SLE patients, Dnase1 activity was found to be significantly lower in SLE patients compared to healthy controls, which negatively correlated with anti-Nucleosome antibody titers. No correlation was found between reduced DNase1 activity and SLE disease flare-ups or kidney complications in this cohort (139). Notably, kidney biopsies from 10 patients were screened for DNASE1 activity of which 4 patients had SLE-associated nephropathy. These 4 patients showed a concurrent low enzymatic activity of DNASE1 compared to healthy controls (140). In agreement with these observations, a reduction in DNASE1 expression in kidney, and urine directly correlated with progression of lupus nephritis in mouse and in humans with self or transplanted kidneys $(141,142)$. These studies suggest a potential role of locally produced DNase1 in the prevention of immune complex deposition and subsequent kidney nephritis (143).

Unlike its role in anti-DNA responses, the function of Dnase1 in the degradation of NETs is better established. Healthy human serum was able to degrade NETs in vitro and the functional component was identified to be DNase1. Conversely, sera from $36.1 \%$ of 61 SLE patients had poor or no ability to degrade NETs in vitro. These patients were found to have high antiNET Abs which hampered the accessibility of DNASE1 to NETs, Notably, in this cohort of SLE patients the poor NET degraders had severe kidney nephritis (94) - further supporting a potential role of DNase1 in preventing kidney nephritis. Recently, NET degradation activity of Dnase1 was further corroborated when Dnase1 was also shown to have a redundant function along with DNase1L3 in the degradation of NETs formed during sterile neutrophilia and septicemia. The absence of DNase1 and DNase1L3 both caused vascular obstruction and organ damage. The results were consistent with human sera samples and in two different mouse models of DNase1 deficiency (82). This chromatin-degrading effect of Dnasel seems to be specific to NET-associated DNA as the quality and quantity of cfDNA fragmentation was indistinguishable between plasma from WT and DNase $1^{-/-}$mice (144). Overall, the available data from SLE patients and DNase $1^{-/}$mice do not indicate its involvement in anti-DNA antibody responses, whereas its role in SLE-related renal pathogenesis is prominent and deserves further exploration.

\section{DNase1 Like 3: Major Negative Regulator of Anti-DNA Responses}

As the name indicates, DNase1L3 bears close structural and functional resemblance with DNase1 and together they comprise the secreted endonucleases in the serum (145). DNase1L3 is one of the family members of three homologous DNase1 like proteins. The DNase domain of all the Dnase1 family of enzymes is highly conserved, while the $\mathrm{C}$ terminal domains are most variable and may impart unique attributes to the enzymes. DNase1 and DNase1L2 lack a C-terminal domain, while DNase1L1 has a GPI-anchored hydrophobic region. DNase1L3 contains a positively charged C terminal domain (146). Homology modeling suggested that the C-terminal peptide of DNase1L3 may stretch out at a fixed angle from the main DNase domain with a stable $\alpha$-helical secondary structure bearing a positive charge (67). Upon deletion of the C-terminal domain or modulation of its conformation, DNase1L3 lost its unique abilities of (1) efficiently degrading DNA within polynucleosomes and (2) digesting liposome-coated DNA (67, 147). Although the exact mechanism by which the C-terminal domain of DNase1L3 imparts the protein its unique ability to access lipid-encapsulated and histone-protected DNA is not clear, the positive charge on the $\alpha$-helix may facilitate lipid membrane binding/ penetration and dislocation of histones from DNA. This unique structural property of DNase1L3 poises it to digest MPassociated DNA and prevent accumulation of extracellular DNA, thereby suppressing SLE. Indeed, we found that IgG from sera of at least $2 / 3 \mathrm{rd}$ of the 53 patients with sporadic SLE, bound to the surface of MPs. Pre-treatment of MPs with DNase1L3 abolished this binding in half of the patients indicating that the IgG binding on the surface of MPs was DNase1L3-sensitive (67). This finding could have implications in using DNase1L3 as a therapeutic to reduce MP-DNA-dependent immune complex formation. DNase1L3 was also recently shown to degrade intravascular NETDNA and prevent vascular occlusion by disrupting NET clots similar to DNase1 (82).

The role of DNase1L3 in autoimmunity was discovered during clinical human patient analysis, summarized in Table 2. A homozygous 1-bp deletion in DNASE1L3 (c.643delT) caused pediatric-onset familial SLE (148). Homozygous frameshift mutations-c.289_290delAC and c.320+4delAGTA in DNASE1L3 led to exon skipping and pediatric SLE in two respective families (149). Recently, four Italian affected individuals were identified with similar mutations in DNASE1L3 (150). In addition to null mutations, SNPs have also been reported in DNASE1L3 in humans. A heterozygous SNP C686/T686 resulting in R206C substitution in DNASE1L3 was found to reduce the DNase1L3 enzymatic activity (151). Furthermore, SNPs in DNase1L3 gene have also been associated with a related autoimmune disease Scleroderma (152, 153). Similar to humans, DNase1L3-deficient (DNase1L3KO) mice (on a pure B6 or pure129 background) develop SLE-like symptoms, including the gender-neutral formation of high titers of anti-DNA abs at an early age (67). Recently, another strain of DNase1L3KO mice was shown to develop antiDNA responses that were further enhanced in SLE-prone mice (154). In striking contrast with all other nucleases, the anti-DNA responses in DNase1L3KO mice were STINGindependent but MyD88-dependent (67). These data identify DNase1L3 as a DNase that is uniquely structured to access and degrade DNA associated with lipids and DNAbinding proteins. It forms an essential component of the DNase arsenal, in the absence of which extracellular DNA escapes degradation and can be a direct autoantigen for the activation and proliferation of DNA-reactive B cells. In 
TABLE 2 | Known cases of DNASE1L3 mutations in human subjects.

\begin{tabular}{|c|c|c|c|c|}
\hline & Cohort details & Identified mutations in DNASE1L3 & Disease characteristics & Reference \\
\hline 1. & $\begin{array}{l}6 \text { families } \\
17 \text { affected subjects (6 Females. } 11 \text { males) }\end{array}$ & Homozygous 1-bp deletion c.643deiT & $\begin{array}{l}\text { ANA }^{+v e}, \text { Anti-dsDNA } \\
\text { Hypocomplementemia } \\
\text { Nephritis in } 10 \text { subjects } \\
\text { SLE in all subjects with SLEDAl: 8-22 }\end{array}$ & $(148)$ \\
\hline 2. & $\begin{array}{l}2 \text { families } \\
5 \text { affected subjects } \\
\text { (All females) }\end{array}$ & $\begin{array}{l}\text { Homozygousframeshift mutation. } \\
\text { c.289_290deiAC and c.320+4deiAGTA }\end{array}$ & $\begin{array}{l}\text { HUVS in all subjects } \\
\text { SLE in } 4 \text { subjects } \\
\text { ANA }^{+v e}, \text { Anti-dsDNA }{ }^{+v e}, \text { ANCA }^{+v e} \\
\text { Hypocomplementemia } \\
\text { Nephntis(classll-111) in } 3 \text { subjects }\end{array}$ & (149) \\
\hline 3. & $\begin{array}{l}1 \text { family } \\
4 \text { affected subjects } \\
\text { ( } 2 \text { females. } 2 \\
\text { males) }\end{array}$ & $\begin{array}{l}\text { Homozygous } 2 b \text { frameshift deletion } \\
\text { c.289_290deiAC }\end{array}$ & $\begin{array}{l}\mathrm{ANA}^{+\mathrm{ve}}, \text { Anti-dsDNA }^{+\mathrm{ve}}, \mathrm{ANCA}^{+\mathrm{ve}} \\
\text { Polyarthritis Glomerulonephritis } \\
\text { Vasculitis Hypocomplementemia }\end{array}$ & $(150)$ \\
\hline 4. & $\begin{array}{l}9 \text { populalons } \\
>90 \text { subjects per group }\end{array}$ & $\begin{array}{l}\text { Heterozygous SNP C686fT686 resulting in } \\
\text { R206C substitution } \\
\text { Found mainly in European } \\
\text { Populations }\end{array}$ & $\begin{array}{l}\text { Reduced Dnase } 1 \text { L3 enzymatic activity } \\
\text { Disease association not studied }\end{array}$ & $(151)$ \\
\hline
\end{tabular}

agreement, DNase1L3-deficient patients and DNase1L3KO mice show the development of anti-DNA Abs at a very early age.

Altogether, as depicted in Figure 1, these studies on nucleases provide evidence that (1) Anti-DNA responses are not induced by excessive IFN production per se, arguing that IFNs play a major role in the amplification of antiDNA responses but not in the breakdown of tolerance to DNA. (2) Extracellular availability of immunogenic DNA as a direct antigen drives anti-DNA reactive $B$ cell responses in SLE, making a strong case for the regulatory role of extracellular DNases in anti-DNA antibody production.

\section{Nucleic Acid Sensors: The Double-Edged Sword}

It is now well-established that microbial NA sensors also recognize self-NAs under autoimmune conditions (69, 155, 156). For that reason, self-NA availability to NA-sensors is limited by nucleases and the availability of several NAsensors is stringently controlled by their localization inside endosomes and by post translational processing for function (157). Together, they prevent self-NA availability and sensing. The contribution of DNA and RNA-sensors in autoimmunity has been the topic of several comprehensive reviews (158, 159). Here we highlight some key points related to the DNA-sensors involved specifically in the antibody response to DNA. We discuss literature which emphasizes the prominent role of endosomal TLRs in DNA sensing to generate an "autoantibody response," unlike the cytosolic DNA sensors which mainly engage an "autoinflammatory response." All the DNA and RNA-sensors are intracellular and further divided into two groups-cytosolic or endosomal. In keeping with the main theme of this review, we discuss the known NA-sensing pathways regulated through intracellular and extracellular nucleases.

\section{NA-Sensing Regulated Through Intracellular Nucleases}

Mice deficient in RNaseH2 complex proteins, SAMHD1 and ADAR1 are either embryonically lethal or do not recapitulate human AGS. Yet, they revealed that RNaseH2 or SAMHD1dependent NA-accumulation led to the stimulation of the cGASSTING pathway, while loss of ADAR1 (deaminase) stimulated the RNA sensing MDA5-MAVS pathway (118). Cytosolic DNA sensing due to DNaseIII or Trex1 deficiency stimulated the $\mathrm{cGAS} \rightarrow \mathrm{cGAMP} \rightarrow \mathrm{STING} \rightarrow \mathrm{IRF} 3 \rightarrow \mathrm{IFN} \alpha$ signaling axis $(121,126,131)$. Overall, the predominant response to DNA sensing in the cytosol was autoinflammatory in both humans and mice. Additionally, although antibodies with other specificities were observed, DNA specific antibodies were detected only in a minority of patients $(118,122,124)$. As highlighted in Figure $\mathbf{1}$ in green, these studies point toward the role of cytosolic cGAScGAMP-STING signaling pathway in autoinflammation but not in the initiation of anti-DNA antibody responses.

The contribution of lysosomal DNase 2 in anti-DNA antibody production is complicated partly because of the absence of a viable mouse model and partly due to the paucity of human patients identified with DNASE2 mutations. The absence of DNase2 in mice causes accumulation of apoptotic cell derived DNA in the lysosomes of liver and bone marrow macrophages causing lethal anemia and cell death. DNase2KO mice can be rescued by the deletion of IFNAR. However, "IFNAR-deficient DNase2KO mice develop chronic polyarthritis, splenomegaly, and ANA. The accumulated DNA stimulates the cGAS-STING-IRF3/7 pathway leading to massive type-I interferon production, because the deficiency of either cGAS (131)/ STING (160, 161)/ IRF3 or IRF7 (162)/AIM2 (161) can rescue the mice form prenatal anemia and severe arthritis. While the generation of IFN $\alpha$ and TNF $\alpha$ in DNase2-deficient mice as well as humans is documented, anti-DNA antibody production in DNase2KO mice is not predominant (131, 160, 163). Instead, DNase2-IFNAR-double-deficient mice developed 
antibodies against RNA-associated antigens and splenomegaly in an RNA-driven TLR-dependent manner (161, 163, 164). Further analysis of DNase2 in anti-DNA responses is required as the three DNASE2-deficient patients (age 11-17) reported thus far had fluctuating significant elevations in circulating anti-DNA Abs (130). It is possible that the formation of anti-DNA Abs in these patients and mice is an "after-effect," as a result of polyclonal activation of $\mathrm{B}$ cells due to chronic inflammation and IC formation.

Altogether, the current literature suggests that the cytosolic DNA is detected primarily through the cGAS-STING pathway which induces a potent autoinflammatory response, while the minimal anti-DNA antibody production seems to be a secondary effect. This agrees with the seemingly confounding role of STING in autoimmunity. STING appears to be a potentiator of autoimmune responses by inducing IFN $\alpha$ and downstream ISGs $(165,166)$. Remarkably, patients with overactive STING do not develop detectable anti-DNA Abs $(165,166)$-strengthening the idea that cytosolic STING signaling pathway is not directly involved in anti-DNA responses. Contrary to its autoimmune-stimulatory activity, STING-deficiency was shown to exacerbate autoimmune manifestations including anti-DNA antibody production in MRL. Fas ${ }^{l p r}$ lupus mouse model (167). It is likely that when cytosolic DNA is absent STING functions as a negative regulator of endosomal TLR signaling through yet undiscovered mechanisms. Alternately, when cytosolic DNA is present STING induces IFN $\alpha$ signaling and autoinflammation. Overall, what we can conclude with confidence is that the cGAS-STING pathway does not seem to induce anti-DNA $\mathrm{Ab}$ production.

\section{NA-Sensing Regulated Through Extracellular Nucleases}

As discussed earlier, DNase1 deficiency does not seem to induce anti-DNA responses by itself. However, its local functions reported in the kidney may promote formation of immune complexes laden with DNA, which are known to engage the endosomal TLR9-MyD88 signaling pathway (168). Further studies on DNase1 need to be performed to establish its NAsensing partners.

DNASE1L3-deficient patients and DNase1L3KO mice both develop high titers of anti-DNA Abs at an early age, without a female gender bias. Using DNase1L3KO mice deficient in either STING or MyD88 we found that anti-DNA and anti-nucleosome responses in DNase1L3KO mice are dependent on the TLRMyD88 pathway. Further studies are underway to delineate which MyD88-dependent TLRs are involved in the autoimmune responses to MP-associated DNA in D1L3KO mice. Some studies suggest that DNase1L3 may have intracellular localization with functions in apoptosis and inflammation, reviewed in Keyel PA (119). However, as autoimmunity in DNase1L3KO mice is independent of the cytosolic DNA sensor STING (67), it indicates that the anti-DNA responses are specifically due to the extracellular DNase function of DNase1L3. Indeed, we were able to temporarily reduce the anti-DNA Ab titers in DNase $1 \mathrm{~L} 3 \mathrm{KO}$ mice by transient replenishment of circulating DNase1L3 enzyme
(67). Overall, extracellular DNases predominantly regulate the stimulation of TLR-MyD88 pathway of DNA sensing, highlighted in yellow in Figure 1.

\section{Role of Toll-Like Receptors in Anti-DNA Antibody Production}

Deficiency of the adaptor protein MyD88 ameliorates SLE specific autoantibodies and associated pathology in several lupus mouse strains (169). Expression levels of TLR2, TLR7, TLR9, IFN-alpha, and LY6E (Sca-1) mRNAs in SLE patients are significantly higher than healthy controls, indicating contribution of TLR-MyD88 signaling pathways in the pathogenesis of human lupus (170). Several studies show that circulating DNA-containing ICs correlate positively with anti-dsDNA Ab production in SLE patients $(171,172)$. Indeed, the importance of BCR/TLR-dual signaling in autoimmune B cell responses was originally identified by using IC-mediated activation of IgG2a-reactive murine AM14 B cells (69). However, it is now clear that TLR engagement also promotes activation, proliferation/ differentiation of B cells that directly bind DNA (or other autoantigens) through the BCR and may therefore play an important role in the early stages of autoantibody production. Among the MyD88-dependent TLRs-TLR7 and TLR9 are the prominent ones involved in the development of anti-DNA Abs in mouse models of lupus and altered TLR7 and 9 expression has been reported in human SLE patients as well (173). Perhaps the most convincing evidence for the involvement of TLR7/9 signaling in B cells for anti-DNA antibody production comes from the case studies of SLE patients that develop an antibody deficiency syndrome similar to common variable immunodeficiency (CVID). These patients have a complete remission from SLE, with absence of anti-DNA Abs, and B cells are unresponsive to TLR7/9 stimulationindicating the crucial role of TLR7/9 mediated B cell responses in SLE $(174,175)$.

\section{TLR7- the Master of RNA-Driven SLE Pathogenesis}

The seminal role of TLR7 in SLE pathogenesis is firmly established. TLR7 promotes the formation of autoantibodies against RNA and RNA-associated proteins. Deletion of TLR7 reduces anti-SmRNP and other RNA-associated antibody responses, however, in most cases there is no reduction in antiDNA responses $(158,176,177)$. It was shown that B cell-intrinsic TLR7 signaling is essential for the formation of spontaneous germinal centers (178). Therefore, in the B6. Sle1b lupus mouse model where autoantibody formation is driven predominantly through the GC-pathway (179), TLR7 deficiency also reduces anti-DNA Abs (178, 180). Most-importantly, deficiency of TLR7 ameliorates SLE-associated splenomegaly and nephritis $(176,181)$, while expression of an extra copy of TLR7 exacerbates it (182). Altogether, TLR7 is the master regulator of RNA-driven TLR-dependent systemic autoimmune manifestations. However, it does not seem to play a direct role in anti-DNA antibody production and yet appears indirectly involved in SLE though 
its functions in molecular pathways necessary for antibody production and inflammation.

\section{The Dichotomous Pathogenic and Tolerogenic Role of TLR9 in Autoimmunity}

By far the most confounding endosomal TLR is TLR9, which is endowed with both pathogenic and regulatory functions. It is required for the generation of high-titer antibodies to DNA and DNA-associated proteins in several murine lupus models including MRL/Fas ${ }^{\text {pr }}$, B6. Sle 1b and Fc $\gamma \mathrm{RIIB}^{-/-}(158,169$, 176, 178). However, even though anti-DNA specific B cells and antibody titers are reduced in the absence of TLR9, there is an exacerbation of lupus pathogenesis (splenomegaly, nephritis, etc.) and an increase in autoantibodies against RNA-associated antigens $(176,177,181,183,184)$-suggesting a negative regulatory or tolerogenic role for TLR9 in the pathogenesis of lupus, by suppressing TLR7-mediated autoimmunity. Similar regulatory role of TLR9 was demonstrated in pristane-induced murine lupus. Pristane exposed TLR9-deficient BALB/c mice had an exacerbated production of autoantibodies against RNA, neutrophil cytoplasmic antigens, and myeloperoxidase and worse renal disease than TLR9-sufficient mice (185). TLR9 has also been shown to promote production of protective IgM antibodies by B-1b cells and prevent expansion of proinflammatory Th17 T cells, thereby regulating systemic autoimmunity (186). Recently, another potential mechanism contributing to the regulatory role of TLR9 was described. Exposure of phagocytes to apoptotic cellassociated DNA (a common antigenic source in experimental lupus), upregulated the expression of the transcription factor AhR (aryl hydrocarbon receptor) in a TLR9-dependent manner. AhR in turn drove the production of the immunoregulatory cytokine IL-10. Therefore, loss of TLR9 or AhR in lupus prone mice exacerbated disease (187). These studies indicate that TLR9 stimulation by DNA in macrophages could be immunosuppressive. However, B cells may not be subject to the same suppressive effects as they are poor phagocytes and this aspect needs further investigation.

\section{A Potential Role of Surface TLRs in Anti-DNA Responses}

Several studies indicate an indirect contribution of cell surface TLRs in anti-DNA antibody production through HMGB1 which is a DNA binding protein known to stimulate TLR-signaling and induce a proinflammatory program (188). In C57BL/6 $6^{\mathrm{pr} / \mathrm{lpr}}$ mice deficient in TLR2 or TLR4, glomerular IgG deposition and mesangial cell proliferation were remarkably decreased, and ANA, anti-dsDNA, and anti-cardiolipin autoantibody titers were significantly reduced (189). Moreover, TLR2-deficiency significantly reduced anti-DNA/nucleosome antibodies, renal disease, and IL-6 production in a pristane-induced lupus mouse model (190). Similarly, in SLE patients, HMGB1 in circulating DNA-containing ICs from SLE patients induced production of anti-dsDNA Abs through the TLR2-MyD88 pathway in-vitro (172). Recently, amyloid curli-DNA complexes were also shown to stimulate TLR9 via TLR2 (87).
In summary, the studies so far suggest a central role for TLR9 in the induction of anti-DNA antibody responses, supported by TLR7, 2, and 4. TLR9 is the only direct endosomal DNA sensor and induces a robust IFN response upon stimulation. However, its endosomal localization limits its accessibility. Therefore, ICmediated internalization through Fc-receptors or direct BCR mediated uptake of DNA are the most potent inducers of TLR9 and anti-DNA Abs. Surface TLRs might play a role in aiding the delivery of DNA to TLR9. However, for long-lived plasma cell formation the germinal center pathway of differentiation is necessary. TLR7 plays a key role in the formation of spontaneous GCs, probably via stimulation through endogenous retroelements (191). Therefore, TLR7 signaling could further promote anti-DNA responses via the GC-pathway. It is more likely that for an effective anti-DNA B cell response all these TLRs-TLR9, TLR7, and TLR2/4 are required in tandem and the inflammatory program induced by them which includes cytokines like IFN $\alpha$, IFN $\gamma$, IL-6, IL-10, and TNF $\alpha$ is necessary for the amplification of DNA-reactive B cells.

\section{Interferons: Key Effectors in the Development and Progression of Anti-DNA Responses and SLE Pathogenesis} Type-I Interferons: Prominent Role of IFN $\alpha$ in Anti-DNA Responses

The three main pathways of type-I interferon induction include sensing by (1) cGAS-STING, (2) RIG-I/MDA5-MAVS, and (3) TLR-MyD88/TRIF. Their involvement in the pathogenesis of several rheumatic diseases and the current therapeutic interventions targeting the type-I interferon pathway have been extensively discussed in excellent reviews elsewhere $(192,193)$. Type1 interferons are at the core of several disease manifestations in monogenic disorders discussed above, so much so that most of the symptoms have been classified separately as "type-I interferonopathies," with AGS as the prototype. Loss of function mutations in cytosolic DNA/RNA processing enzymes and gain of function mutations in the ds-RNA receptor gene IFIH1 (MDA5) $(194,195)$ and adapter protein TMEM173 (STING) cause excessive type-I IFN production leading to severe disease pathologies $(122,196)$. However, as discussed in previous sections, the induction of type-I interferons by the stimulation of cytosolic NA sensors does not seem to engage the pathways directly responsible for anti-DNA antibody production, although it is crucial for disease manifestations with features overlapping that of rheumatic diseases.

On the other hand, accumulating evidence implicates the TLR pathway of type-I IFN production as a major pathway of antiDNA Ab production. The most convincing data is from SLE patients with genetic variations in the major proteins involved in the TLR-IFN signaling axis. Polymorphisms in TLR signaling pathway proteins such as IRF5, IRF7, IRF8, and IRAK1 are associated with SLE $(197,198)$. Most of the polymorphisms in IRFs directly correlate with high anti-DNA and anti-Ro/La/Sm antibodies which result in increased IFN $\alpha$ activity (199-201). These studies suggest a crucial role of autoantibody-DNA/ RNA complexes in the stimulation of the TLR pathway resulting in 
increased type I IFN production (Figure 1), which feeds into an amplification loop. Although the role of ICs in the production of type-I IFNs is clear, whether they are directly involved in the generation of autoantibodies found in those ICs is less understood. In this regard, understanding the direct vs. indirect effects of type-I IFNs on B cells may be critical. Indeed, a number of studies have looked at the effect of IFN $\alpha$ on B cells in various lupus-prone mouse models by overexpressing IFN $\alpha$ through adenovirus in NZB/W-F1, NZW/BXSB and B6. Sle1,2,3, reviewed in Liu et al. (202); or by deleting the IFN $\alpha$ receptor in B cells of B6. Sle1b (203) and WASp-chimeric (204) experimental lupus models. In all these models IFN $\alpha$ signaling positively correlated with $B$ cell activation and differentiation into GC B cells and antibody-forming cells and high anti-DNA Ab titers. In the B6. Sle $1 b$ model, IFN $\alpha$ specifically promoted autoreactive B cell expansion and positive selection through the germinal center pathway but was dispensable for $\mathrm{B}$ cell responses against foreign antigens (203). Interestingly, in most experimental models, IFN $\alpha$ production through the TLR7 signaling pathway seems to play a major role in SLE by either regulating germinal center formation or by promoting the generation of IC-forming pathogenic autoantibodies that ultimately cause kidney pathology. TLR9deficieny in MRL.Fas(lpr) mice caused exacerbated renal disease which was abrogated in the absence of IFNAR-signaling through specific reduction of anti-RNA specific antibodies (205), suggesting a crucial role of TLR7-IFN $\alpha$ signaling axis in SLE pathogenesis. In DNase1L3-deficient mice where increased accumulation of undigested cfDNA leads to specific production of anti-chromatin and anti-DNA antibodies through the TLRMyD88 pathway, IFN $\alpha$ overexpression exacerbated anti-DNA responses and mortality (67). Collectively, these studies establish an important role of type I IFN in autoantibody-driven inflammation, although it has been difficult to distinguish its effects on autoantibody production per se vs. the downstream inflammatory process.

\section{IFN Gamma: Initiator of Anti-DNA Antibodies in SLE?}

Type-II IFN (IFN $\gamma$ ) has been implicated in both human and mouse lupus (206). Accumulation of autoantibodies has been shown to precede clinical presentation of SLE disease by several years (2). A comprehensive longitudinal analysis of lupus autoantibodies, IFN $\alpha$, and IFN $\gamma$ from serum samples of 55 patients before and after clinical onset of SLE, with matched controls was performed. The study revealed that in SLE patients, autoantibodies appear years before clinical SLE is detectable but notably they either coincided with or followed an increase in IFN $\gamma$. In contrast, increase in IFN $\alpha$ was observed mostly at the time of detectable clinical disease (207). These findings suggest IFN $\gamma$ as the initiator and IFN $\alpha$ as the propagator of autoantibody production. In line with this model, recently, in two independent studies with B6. Sle1b or WASp murine models of lupus, deletion of IFN $\gamma$ receptor in B cells led to a complete loss of germinal centers, abolishment of anti-dsDNA Abs and systemic autoimmune manifestations $(204,208)$. In WASp chimeric mice and in human B cells, IFN $\gamma$ signaling along with BCR/CD40 and TLR signaling was shown to be necessary for the induction of Bcl6 , the master regulator of GC responses (204). Alternately, in the
B6. Sle $1 b$ model, IFN $\gamma$ signaling through STAT1 was required for the expression of transcription factor T-bet, and IFN $\gamma$ production in B cells, which then differentiated into pathogenic anti-DNA IgG2b/2c producing cells (208). Interestingly, a subset of B cells expressing T-bet, CD11c, and IFN $\gamma$ named age-associated B cells (ABCs), have been implicated in SLE pathogenesis as well (209). Moreover, upon deletion of IFN $\gamma$ a dramatic decrease in antidsDNA antibodies of IgG2a subclass and reduced proliferation of B cells was also observed in the MRL-FAS (lpr) mice (210), where anti-DNA antibody production occurs mainly through the extrafollicular pathway (20). Overall, these studies highlight the important role of IFN $\gamma$ signaling in the GC, extrafollicular, and $\mathrm{ABC}$-associated pathways of anti-DNA antibody production. Several studies describing IFN $\gamma$ in SLE, highlight the role of T cells in the production of pathogenic IFN $\gamma$ (204). Indeed, a higher percentage of $\mathrm{CD} 4^{+}$and $\mathrm{CD} 8^{+} \mathrm{T}$ cells from SLE patients produce excessive IFN $\gamma$ (211). Additionally, Tfh mediated autoimmunity in Roquin ${ }^{\text {san/san }}$ mice was induced by the accumulation of excessive IFN $\gamma$ producing $\mathrm{T}$ cells due to delayed degradation of IFN $\gamma$ mRNA (212). Considering the evident importance of IFN $\gamma$ in autoimmunity, neutralization, or reduction of IFN $\gamma$ has been tried as a therapeutic modality in mice and human SLE. Significant reduction in autoimmunity was observed in NZB/NZW-F1, MRL. Fas ${ }^{l p r}$ and pristane induced mouse model of lupus, however, due to the crucial role of IFN $\gamma$ in antiviral immunity in humans, the usefulness of IFN $\gamma$ blockade in SLE may be limited (206).

Overall, the role of interferons in anti-DNA Ab production is well-established. However, due to the significant overlap between the genes induced by $\operatorname{IFN} \alpha$ and $\operatorname{IFN} \gamma(213,214)$, it is harder to delineate their individual contribution to autoantibody production and SLE pathogenesis. Based on the evidence discussed above, it is plausible that under autoimmune conditions (in the presence of cfDNA/RNA or cell-intrinsic defects), autoantibody production is initiated by the stimulation of B cells by antigen-stimulated IFN $\gamma$-producing $\mathrm{T}$ cells, leading to autoreactive $\mathrm{B}$ cell proliferation and differentiation. The autoantibodies produced thereby form complexes with the cfDNA/RNA may then promote $\mathrm{pDC} / \mathrm{DC}$ activation and IFN $\alpha$ production, which would further amplify the response, as shown in the schematic in Figure 1.

\section{CONCLUSIONS}

Emerging genetic and functional evidence suggests that the efficient degradation of extracellular DNA is an important checkpoint in preventing the stimulation of DNA-reactive B cells. As depicted in Figure 1, a B cell-intrinsic TLR-MyD88 pathway of DNA recognition seems to be necessary for the break in tolerance to DNA, supported by helper T cells recognizing DNAassociated antigens. These autoreactive B cells could further proliferate and differentiate in response to type-I IFNs produced by themselves and by myeloid/ stromal cells, thereby amplifying the autoantibody response. Therefore, using interventions that could enhance or amplify the degradation of extracellular DNA may work to impede the production of anti-DNA antibodies and could be tested as a therapeutic for SLE. 


\section{AUTHOR CONTRIBUTIONS}

All authors listed have made a substantial, direct and intellectual contribution to the work, and approved it for publication.

\section{REFERENCES}

1. Casals SP, Friou GJ, Myers LL. Significance of antibody to DNA in systemic lupus erythematosus. Arthritis Rheum. (1964) 7:379-90. doi: 10.1002/art.1780070404

2. Arbuckle MR, Mcclain MT, Rubertone MV, Scofield RH, Dennis GJ, James JA, et al. Development of autoantibodies before the clinical onset of systemic lupus erythematosus. N Engl J Med. (2003) 349:1526-33. doi: 10.1056/NEJMoa021933

3. Bentow C, Lakos G, Martis P, Wahl E, Garcia M, Vinas O, et al. International multi-center evaluation of a novel chemiluminescence assay for the detection of anti-dsDNA antibodies. Lupus. (2016) 25:864-72. doi: 10.1177/0961203316640917

4. Pisetsky DS. Anti-DNA antibodies-quintessential biomarkers of SLE. Nat Rev Rheumatol. (2016) 12:102-10. doi: 10.1038/nrrheum.2015.151

5. Ter Borg EJ, Horst G, Hummel EJ, Limburg PC, Kallenberg CG. Measurement of increases in anti-double-stranded DNA antibody levels as a predictor of disease exacerbation in systemic lupus erythematosus. A long-term, prospective study. Arthritis Rheum. (1990) 33:634-43. doi: 10.1002/art.1780330505

6. Merrill J, Buyon J, Furie R, Latinis K, Gordon C, Hsieh HJ, et al. Assessment of flares in lupus patients enrolled in a phase II/III study of rituximab. (EXPLORER). Lupus. (2011) 20:709-16. doi: 10.1177/0961203310395802

7. Petri MA, Van Vollenhoven RF, Buyon J, Levy RA, Navarra SV, Cervera R, et al. Baseline predictors of systemic lupus erythematosus flares: data from the combined placebo groups in the phase III belimumab trials. Arthritis Rheum. (2013) 65:2143-53. doi: 10.1002/art.37995

8. Attar SM, Koshak EA. Medical conditions associated with a positive antidouble-stranded deoxyribonucleic acid. Saudi Med J. (2010) 31:781-7.

9. Font J, Cervera R, Ramos-Casals M, Garcia-Carrasco M, Sents J, Herrero $\mathrm{C}$, et al. Clusters of clinical and immunologic features in systemic lupus erythematosus: analysis of 600 patients from a single center. Semin Arthritis Rheum. (2004) 33:217-30. doi: 10.1053/S0049-0172(03)00133-1

10. Yung S, Chan TM. Mechanisms of kidney injury in lupus nephritis - the role of anti-dsDNA Antibodies. Front Immunol. (2015) 6:475. doi: 10.3389/fimmu.2015.00475

11. Biesen R, Dahnrich C, Rosemann A, Barkhudarova F, Rose T, Jakob O, et al. Anti-dsDNA-NcX ELISA: dsDNA-loaded nucleosomes improve diagnosis and monitoring of disease activity in systemic lupus erythematosus. Arthritis Res Ther. (2011) 13:R26. doi: 10.1186/ar3250

12. Ruffatti A, Calligaro A, Del Ross T, Bertoli MT, Doria A, Rossi L, et al. Anti-double-stranded DNA antibodies in the healthy elderly: prevalence and characteristics. J Clin Immunol. (1990) 10:300-3. doi: 10.1007/BF00917474

13. Dorner T, Lipsky PE. B cells: depletion or functional modulation in rheumatic diseases. Curr Opin Rheumatol. (2014) 26:228-36. doi: 10.1097/BOR.0000000000000000

14. Hofmann K, Clauder AK, Manz RA. Targeting B cells and plasma cells in autoimmune diseases. Front Immunol. (2018) 9:835. doi: 10.3389/fimmu.2018.00835

15. Rekvig OP. Anti-dsDNA antibodies as a classification criterion and a diagnostic marker for systemic lupus erythematosus: critical remarks. Clin Exp Immunol. (2015) 179:5-10. doi: 10.1111/cei.12296

16. Suurmond J, Calise J, Malkiel S, Diamond B. DNA-reactive B cells in lupus. Curr Opin Immunol. (2016) 43:1-7. doi: 10.1016/j.coi.2016.07.002

17. Shlomchik MJ. Sites and stages of autoreactive B cell activation and regulation. Immunity. (2008) 28:18-28. doi: 10.1016/j.immuni.2007.12.004

18. Domeier PP, Schell SL, Rahman ZS. Spontaneous germinal centers and autoimmunity. Autoimmunity. (2017) 50:4-18. doi: $10.1080 / 08916934.2017 .128067$

\section{ACKNOWLEDGMENTS}

This work was supported by the NIH grants AI072571, AR071703, and AR070591, the Lupus Research Alliance and the Colton Center for Autoimmunity.

19. Mackay F, Woodcock SA, Lawton P, Ambrose C, Baetscher M, Schneider $\mathrm{P}$, et al. Mice transgenic for BAFF develop lymphocytic disorders along with autoimmune manifestations. J Exp Med. (1999) 190:1697-710. doi: 10.1084/jem.190.11.1697

20. William J, Euler C, Christensen S, Shlomchik MJ. Evolution of autoantibody responses via somatic hypermutation outside of germinal centers. Science. (2002) 297:2066-70. doi: 10.1126/science.1073924

21. Hoyer BF, Moser K, Hauser AE, Peddinghaus A, Voigt C, Eilat D, et al Short-lived plasmablasts and long-lived plasma cells contribute to chronic humoral autoimmunity in NZB/W mice. J Exp Med. (2004) 199:1577-84. doi: $10.1084 /$ jem. 20040168

22. Herlands RA, William J, Hershberg U, Shlomchik MJ. Anti-chromatin antibodies drive in vivo antigen-specific activation and somatic hypermutation of rheumatoid factor B cells at extrafollicular sites. Eur J Immunol. (2007) 37:3339-51. doi: 10.1002/eji.200737752

23. Arce E, Jackson DG, Gill MA, Bennett LB, Banchereau J, Pascual V. Increased frequency of pre-germinal center B cells and plasma cell precursors in the blood of children with systemic lupus erythematosus. I Immunol. (2001) 167:2361-9. doi: 10.4049/jimmunol.167.4.2361

24. Jacobi AM, Odendahl M, Reiter K, Bruns A, Burmester GR, Radbruch A, et al. Correlation between circulating CD27high plasma cells and disease activity in patients with systemic lupus erythematosus. Arthritis Rheum. (2003) 48:1332-42. doi: 10.1002/art.10949

25. Jenks SA, Cashman KS, Zumaquero E, Marigorta UM, Patel AV, Wang $\mathrm{X}$, et al. Distinct effector B cells induced by unregulated toll-like receptor 7 contribute to pathogenic responses in systemic lupus erythematosus. Immunity. (2018) 49:725-39.e726. doi: 10.1016/j.immuni.2018.08.015

26. Sanz I. Rationale for B cell targeting in SLE. Semin Immunopathol. (2014) 36:365-75. doi: 10.1007/s00281-014-0430-z

27. Gamble RG, Dellavalle RP. A randomized controlled trial of belimumab for the treatment of active systemic lupus erythematosus. Arch Dermatol. (2012) 148:376-8. doi: 10.1001/archdermatol.2011.1266

28. Stohl W, Hiepe F, Latinis KM, Thomas M, Scheinberg MA, Clarke A, et al. Belimumab reduces autoantibodies, normalizes low complement levels, and reduces select $B$ cell populations in patients with systemic lupus erythematosus. Arthritis Rheum. (2012) 64:2328-37. doi: 10.1002/art.34400

29. Van Vollenhoven RF, Petri MA, Cervera R, Roth DA, Ji BN, Kleoudis CS, et al. Belimumab in the treatment of systemic lupus erythematosus: high disease activity predictors of response. Ann Rheum Dis. (2012) 71:1343-9. doi: 10.1136/annrheumdis-2011-200937

30. Furie R, Petri M, Zamani O, Cervera R, Wallace DJ, Tegzova D, et al. A phase III, randomized, placebo-controlled study of belimumab, a monoclonal antibody that inhibits B lymphocyte stimulator, in patients with systemic lupus erythematosus. Arthritis Rheum. (2011) 63:3918-30. doi: 10.1002/art.30613

31. Navarra SV, Guzman RM, Gallacher AE, Hall S, Levy RA, Jimenez RE, et al. Efficacy and safety of belimumab in patients with active systemic lupus erythematosus: a randomised, placebo-controlled, phase 3 trial. Lancet. (2011) 377:721-31. doi: 10.1016/S0140-6736(10)61354-2

32. Dennis GJ. Belimumab: a BLyS-specific inhibitor for the treatment of systemic lupus erythematosus. Clin Pharmacol Ther. (2012) 91:143-9. doi: 10.1038/clpt.2011.290

33. Ruiz-Irastorza G, Danza A, Khamashta M. Glucocorticoid use and abuse in SLE. Rheumatology. (2012) 51:1145-53. doi: 10.1093/rheumatology/ker410

34. Kasturi S, Sammaritano LR. Corticosteroids in lupus. Rheum Dis Clin North Am. (2016) 42:47-62. doi: 10.1016/j.rdc.2015.08.007

35. Giles JR, Neves AT, Marshak-Rothstein A, Shlomchik MJ. Autoreactive helper T cells alleviate the need for intrinsic TLR signaling in autoreactive B cell activation. JCI Insight. (2017) 2:e90870. doi: 10.1172/jci.insight.90870 
36. Rajagopalan S, Zordan T, Tsokos GC, Datta SK. Pathogenic anti-DNA autoantibody-inducing $\mathrm{T}$ helper cell lines from patients with active lupus nephritis: isolation of CD4-8- T helper cell lines that express the gamma delta T-cell antigen receptor. Proc Natl Acad Sci USA. (1990) 87:7020-4. doi: $10.1073 /$ pnas.87.18.7020

37. Mohan C, Adams S, Stanik V, Datta SK. Nucleosome: a major immunogen for pathogenic autoantibody-inducing T cells of lupus. J Exp Med. (1993) 177:1367-81. doi: 10.1084/jem.177.5.1367

38. Bockenstedt LK, Gee RJ, Mamula MJ. Self-peptides in the initiation of lupus autoimmunity. J Immunol. (1995) 154:3516-24.

39. Linterman MA, Rigby RJ, Wong RK, Yu D, Brink R, Cannons JL, et al. Follicular helper T cells are required for systemic autoimmunity. J Exp Med. (2009) 206:561-76. doi: 10.1084/jem.20081886

40. Soni C, Domeier PP, Wong EB, Shwetank KTN, Elias MJ, Rahman ZS. Distinct and synergistic roles of Fc $\gamma$ RIIB deficiency and 129 strainderived SLAM family proteins in the development of spontaneous germinal centers and autoimmunity. J Autoimmun. (2015) 63:31-46. doi: 10.1016/j.jaut.2015.06.011

41. Vinuesa CG, Linterman MA, Yu D, Maclennan IC. Follicular helper T cells. Annu Rev Immunol. (2016) 34:335-68. doi: 10.1146/annurev-immunol-041015-055605

42. Simpson N, Gatenby PA, Wilson A, Malik S, Fulcher DA, Tangye SG, et al. Expansion of circulating $\mathrm{T}$ cells resembling follicular helper $\mathrm{T}$ cells is a fixed phenotype that identifies a subset of severe systemic lupus erythematosus. Arthritis Rheum. (2010) 62:234-44. doi: 10.1002/art.25032

43. Kim SJ, Lee K, Diamond B. Follicular helper $\mathrm{T}$ cells in systemic lupus erythematosus. Front Immunol. (2018) 9:1793. doi: 10.3389/fimmu.2018.01793

44. Odegard JM, Marks BR, Diplacido LD, Poholek AC, Kono DH, Dong C, et al. ICOS-dependent extrafollicular helper T cells elicit IgG production via IL-21 in systemic autoimmunity. J Exp Med. (2008) 205:2873-86. doi: 10.1084/jem.20080840

45. Lee SK, Rigby RJ, Zotos D, Tsai LM, Kawamoto S, Marshall JL, et al. B cell priming for extrafollicular antibody responses requires Bcl-6 expression by T cells. J Exp Med. (2011) 208:1377-88. doi: 10.1084/jem.20102065

46. Sweet RA, Ols ML, Cullen JL, Milam AV, Yagita H, Shlomchik MJ. Facultative role for $\mathrm{T}$ cells in extrafollicular Toll-like receptor-dependent autoreactive B-cell responses in vivo. Proc Natl Acad Sci USA. (2011) 108:7932-7. doi: 10.1073/pnas.1018571108

47. Caielli S, Veiga DT, Balasubramanian P, Athale S, Domic B, Murat E, et al. $\mathrm{A} \mathrm{CD} 4^{+} \mathrm{T}$ cell population expanded in lupus blood provides $\mathrm{B}$ cell help through interleukin-10 and succinate. Nat Med. (2019) 25:75-81. doi: 10.1038/s41591-018-0254-9

48. Crispin JC, Kyttaris VC, Terhorst C, Tsokos GC. T cells as therapeutic targets in SLE. Nat Rev Rheumatol. (2010) 6:317-25. doi: 10.1038/nrrheum.2010.60

49. Dall'era MC, Cardarelli PM, Preston BT, Witte A, Davis JC Jr. Type I interferon correlates with serological and clinical manifestations of SLE. Ann Rheum Dis. (2005) 64:1692-7. doi: 10.1136/ard.2004.033753

50. Kirou KA, Lee C, George S, Louca K, Peterson MG, Crow MK. Activation of the interferon-alpha pathway identifies a subgroup of systemic lupus erythematosus patients with distinct serologic features and active disease. Arthritis Rheum. (2005) 52:1491-503. doi: 10.1002/art.21031

51. Weckerle CE, Franek BS, Kelly JA, Kumabe M, Mikolaitis RA, Green SL, et al. Network analysis of associations between serum interferon- $\alpha$ activity, autoantibodies, and clinical features in systemic lupus erythematosus. Arthritis Rheum. (2011) 63:1044-53. doi: 10.1002/art.30187

52. Reizis B, Bunin A, Ghosh HS, Lewis KL, Sisirak V. Plasmacytoid dendritic cells: recent progress and open questions. Annu Rev Immunol. (2011) 29:163-83. doi: 10.1146/annurev-immunol-031210-101345

53. Ganguly D, Haak S, Sisirak V, Reizis B. The role of dendritic cells in autoimmunity. Nat Rev Immunol. (2013) 13:566-77. doi: 10.1038/nri3477

54. Fiore N, Castellano G, Blasi A, Capobianco C, Loverre A, Montinaro V, et al. Immature myeloid and plasmacytoid dendritic cells infiltrate renal tubulointerstitium in patients with lupus nephritis. Mol Immunol. (2008) 45:259-65. doi: 10.1016/j.molimm.2007.04.029

55. Rowland SL, Riggs JM, Gilfillan S, Bugatti M, Vermi W, Kolbeck R, et al. Early, transient depletion of plasmacytoid dendritic cells ameliorates autoimmunity in a lupus model. J Exp Med. (2014) 211:1977-91. doi: $10.1084 /$ jem.20132620

56. Davison LM, Jorgensen TN. Sialic acid-binding immunoglobulin-type lectin $\mathrm{H}$-positive plasmacytoid dendritic cells drive spontaneous lupus-like disease development in B6.Nba2 mice. Arthritis Rheumatol. (2015) 67:1012-22. doi: 10.1002/art.38989

57. Sisirak V, Ganguly D, Lewis KL, Couillault C, Tanaka L, Bolland S, et al. Genetic evidence for the role of plasmacytoid dendritic cells in systemic lupus erythematosus. J Exp Med. (2014) 211:1969-76. doi: 10.1084/jem.20132522

58. Jego G, Palucka AK, Blanck JP, Chalouni C, Pascual V, Banchereau J. Plasmacytoid dendritic cells induce plasma cell differentiation through type I interferon and interleukin 6. Immunity. (2003) 19:225-34. doi: 10.1016/S1074-7613(03)00208-5

59. Berggren O, Hagberg N, Weber G, Alm GV, Ronnblom L, Eloranta ML. $B$ lymphocytes enhance interferon- $\alpha$ production by plasmacytoid dendritic cells. Arthritis Rheum. (2012) 64:3409-19. doi: 10.1002/art.34599

60. Menon M, Blair PA, Isenberg DA, Mauri C. A regulatory feedback between plasmacytoid dendritic cells and regulatory b cells is aberrant in systemic lupus erythematosus. Immunity. (2016) 44:683-97. doi: 10.1016/j.immuni.2016.02.012

61. Karounos DG, Grudier JP, Pisetsky DS. Spontaneous expression of antibodies to DNA of various species origin in sera of normal subjects and patients with systemic lupus erythematosus. J Immunol. (1988) 140:451-5.

62. Robertson CR, Gilkeson GS, Ward MM, Pisetsky DS. Patterns of heavy and light chain utilization in the antibody response to single-stranded bacterial DNA in normal human subjects and patients with systemic lupus erythematosus. Clin Immunol Immunopathol. (1992) 62:25-32. doi: 10.1016/0090-1229(92)90019-K

63. Gilkeson GS, Pippen AM, Pisetsky DS. Induction of cross-reactive anti-dsDNA antibodies in preautoimmune NZB/NZW mice by immunization with bacterial DNA. J Clin Invest. (1995) 95:1398-402. doi: 10.1172/JCI117793

64. Raptis L, Menard HA. Quantitation and characterization of plasma DNA in normals and patients with systemic lupus erythematosus. J Clin Invest. (1980) 66:1391-9. doi: 10.1172/JCI109992

65. Lui YY, Dennis YM. Circulating DNA in plasma and serum: biology, preanalytical issues and diagnostic applications. Clin Chem Lab Med. (2002) 40:962-8. doi: 10.1515/CCLM.2002.169

66. Jiang P, Lo YMD. The long and short of circulating cell-free DNA and the ins and outs of molecular diagnostics. Trends Genet. (2016) 32:360-71. doi: 10.1016/j.tig.2016.03.009

67. Sisirak V, Sally B, D'agati V, Martinez-Ortiz W, Ozcakar ZB, David J, et al. Digestion of chromatin in apoptotic cell microparticles prevents autoimmunity. Cell. (2016) 166:88-101. doi: 10.1016/j.cell.2016. 05.034

68. Napirei M, Gultekin A, Kloeckl T, Moroy T, Frostegard J, Mannherz HG. Systemic lupus-erythematosus: deoxyribonuclease 1 in necrotic chromatin disposal. Int J Biochem Cell Biol. (2006) 38:297-306. doi: 10.1016/j.biocel.2005.10.023

69. Leadbetter EA, Rifkin IR, Hohlbaum AM, Beaudette BC, Shlomchik MJ, Marshak-Rothstein A. Chromatin-IgG complexes activate B cells by dual engagement of IgM and Toll-like receptors. Nature. (2002) 416:603-7. doi: $10.1038 / 416603 a$

70. Pisetsky DS, Gauley J, Ullal AJ. Microparticles as a source of extracellular DNA. Immunol Res. (2011) 49:227-34. doi: 10.1007/s12026-010-8184-8

71. Nielsen CT, Ostergaard O, Rekvig OP, Sturfelt G, Jacobsen S, Heegaard NH. Galectin-3 binding protein links circulating microparticles with electron dense glomerular deposits in lupus nephritis. Lupus. (2015) 24:1150-60. doi: 10.1177/0961203315580146

72. Beyer C, Pisetsky DS. The role of microparticles in the pathogenesis of rheumatic diseases. Nat Rev Rheumatol. (2010) 6:21-9. doi: 10.1038/nrrheum.2009.229

73. Ullal AJ, Marion TN, Pisetsky DS. The role of antigen specificity in the binding of murine monoclonal anti-DNA antibodies to microparticles from apoptotic cells. Clin Immunol. (2014) 154:178-87. doi: 10.1016/j.clim.2014.05.007 
74. Papayannopoulos V. Neutrophil extracellular traps in immunity and disease. Nat Rev Immunol. (2018) 18:134-47. doi: 10.1038/nri.2017.105

75. Lande R, Gregorio J, Facchinetti V, Chatterjee B, Wang YH, Homey B, et al. Plasmacytoid dendritic cells sense self-DNA coupled with antimicrobial peptide. Nature. (2007) 449:564-9. doi: 10.1038/nature06116

76. Garcia-Romo GS, Caielli S, Vega B, Connolly J, Allantaz F, Xu Z, et al. Netting neutrophils are major inducers of type I IFN production in pediatric systemic lupus erythematosus. Sci Transl Med. (2011) 3:73ra20. doi: 10.1126/scitranslmed.3001201

77. Lande R, Ganguly D, Facchinetti V, Frasca L, Conrad C, Gregorio J, et al. Neutrophils activate plasmacytoid dendritic cells by releasing self-DNApeptide complexes in systemic lupus erythematosus. Sci Transl Med. (2011) 3:73ra19. doi: 10.1126/scitranslmed.3001180

78. Caielli S, Athale S, Domic B, Murat E, Chandra M, Banchereau R, et al. Oxidized mitochondrial nucleoids released by neutrophils drive type I interferon production in human lupus. J Exp Med. (2016) 213:697-713. doi: $10.1084 /$ jem. 20151876

79. Chamilos G, Gregorio J, Meller S, Lande R, Kontoyiannis DP, Modlin RL, et al. Cytosolic sensing of extracellular self-DNA transported into monocytes by the antimicrobial peptide LL37. Blood. (2012) 120:3699-707. doi: 10.1182/blood-2012-01-401364

80. Gestermann N, Di Domizio J, Lande R, Demaria O, Frasca L, Feldmeyer L, et al. Netting neutrophils activate autoreactive B cells in lupus. J Immunol. (2018) 200:3364-71. doi: 10.4049/jimmunol.1700778

81. Khandpur R, Carmona-Rivera C, Vivekanandan-Giri A, Gizinski A, Yalavarthi S, Knight JS, et al. NETs are a source of citrullinated autoantigens and stimulate inflammatory responses in rheumatoid arthritis. Sci Transl Med. (2013) 5:178ral40. doi: 10.1126/scitranslmed.3005580

82. Jimenez-Alcazar M, Rangaswamy C, Panda R, Bitterling J, Simsek YJ, Long AT, et al. Host DNases prevent vascular occlusion by neutrophil extracellular traps. Science. (2017) 358:1202-6. doi: 10.1126/science.aam8897

83. Wang H, Li T, Chen S, Gu Y, Ye S. Neutrophil extracellular trap mitochondrial DNA and its autoantibody in systemic lupus erythematosus and a proof-of-concept trial of metformin. Arthritis Rheumatol. (2015) 67:3190-200. doi: 10.1002/art.39296

84. Lood C, Blanco LP, Purmalek MM, Carmona-Rivera C, De Ravin SS, Smith CK, et al. Neutrophil extracellular traps enriched in oxidized mitochondrial DNA are interferogenic and contribute to lupus-like disease. Nat Med. (2016) 22:146-53. doi: $10.1038 / \mathrm{nm} .4027$

85. Manfredo Vieira S, Hiltensperger M, Kumar V, Zegarra-Ruiz D, Dehner C, Khan N, et al. Translocation of a gut pathobiont drives autoimmunity in mice and humans. Science. (2018) 359:1156-61. doi: 10.1126/science.aar7201

86. Rekvig OP, Moens U, Sundsfjord A, Bredholt G, Osei A, Haaheim H, et al. Experimental expression in mice and spontaneous expression in human SLE of polyomavirus T-antigen. A molecular basis for induction of antibodies to DNA and eukaryotic transcription factors. J Clin Invest. (1997) 99:2045-54. doi: $10.1172 / J C I 119373$

87. Tursi SA, Lee EY, Medeiros NJ, Lee MH, Nicastro LK, Buttaro B, et al. Bacterial amyloid curli acts as a carrier for DNA to elicit an autoimmune response via TLR2 and TLR9. PLoS Pathog. (2017) 13:e1006315. doi: 10.1371/journal.ppat.1006315

88. Lv S, Zhang J, Wu J, Zheng X, Chu Y, Xiong S. Origin and anti-tumor effects of anti-dsDNA autoantibodies in cancer patients and tumor-bearing mice. Immunol Lett. (2005) 99:217-27. doi: 10.1016/j.imlet.2005.03.019

89. Compagno M, Rekvig OP, Bengtsson AA, Sturfelt G, Heegaard NH, Jönsen A, et al. Clinical phenotype associations with various types of anti-dsDNA antibodies in patients with recent onset of rheumatic symptoms. Results from a multicentre observational study. Lupus Sci Med. (2014) 1:e000007. doi: 10.1136/lupus-2013-000007

90. Serpas L, Chan RWY, Jiang P, Ni M, Sun K, Rashidfarrokhi A, et al. Dnasell3 deletion causes aberrations in length and end motif frequencies in plasma DNA. Proc Natl Acad Sci USA. (2019) 116:641-9. doi: $10.1073 /$ pnas. 1815031116

91. Lo YM, Corbetta N, Chamberlain PF, Rai V, Sargent IL, Redman CW, et al. Presence of fetal DNA in maternal plasma and serum. Lancet. (1997) 350:485-7. doi: 10.1016/S0140-6736(97)02174-0

92. Pisetsky DS. The origin and properties of extracellular DNA: from PAMP to DAMP. Clin Immunol. (2012) 144:32-40. doi: 10.1016/j.clim.2012.04.006
93. Villanueva E, Yalavarthi S, Berthier CC, Hodgin JB, Khandpur R, Lin AM, et al. Netting neutrophils induce endothelial damage, infiltrate tissues, and expose immunostimulatory molecules in systemic lupus erythematosus. $J$ Immunol. (2011) 187:538-52. doi: 10.4049/jimmunol.1100450

94. Hakkim A, Furnrohr BG, Amann K, Laube B, Abed UA, Brinkmann $\mathrm{V}$, et al. Impairment of neutrophil extracellular trap degradation is associated with lupus nephritis. Proc Natl Acad Sci USA. (2010) 107:9813-8. doi: 10.1073/pnas.0909927107

95. Farrera C, Fadeel B. Macrophage clearance of neutrophil extracellular traps is a silent process. J Immunol. (2013) 191:2647-56. doi: 10.4049/jimmunol.1300436

96. Lande R, Chamilos G, Ganguly D, Demaria O, Frasca L, Durr S, et al. Cationic antimicrobial peptides in psoriatic skin cooperate to break innate tolerance to self-DNA. Eur J Immunol. (2015) 45:203-13. doi: $10.1002 /$ eji.201344277

97. Ronnblom L, Pascual V. The innate immune system in SLE: type I interferons and dendritic cells. Lupus. (2008) 17:394-9. doi: 10.1177/0961203308090020

98. Pisetsky DS. The role of mitochondria in immune-mediated disease: the dangers of a split personality. Arthritis Res Ther. (2016) 18:169. doi: 10.1186/s13075-016-1063-5

99. Gkirtzimanaki K, Kabrani E, Nikoleri D, Polyzos A, Blanas A, Sidiropoulos P, et al. IFN $\alpha$ impairs autophagic degradation of mtDNA promoting autoreactivity of SLE monocytes in a STING-dependent fashion. Cell Rep. (2018) 25:921-33.e925. doi: 10.1016/j.celrep.2018.09.001

100. Monteith AJ, Kang S, Scott E, Hillman K, Rajfur Z, Jacobson K, et al. Defects in lysosomal maturation facilitate the activation of innate sensors in systemic lupus erythematosus. Proc Natl Acad Sci USA. (2016) 113:E2142-51. doi: 10.1073/pnas.1513943113

101. Poon IK, Lucas CD, Rossi AG, Ravichandran KS. Apoptotic cell clearance: basic biology and therapeutic potential. Nat Rev Immunol. (2014) 14:166-80. doi: $10.1038 /$ nri3607

102. Lou H, Pickering MC. Extracellular DNA and autoimmune diseases. Cell Mol Immunol. (2018) 15:746-55. doi: 10.1038/cmi.2017.136

103. Radic M, Marion T, Monestier M. Nucleosomes are exposed at the cell surface in apoptosis. J Immunol. (2004) 172:6692-700. doi: 10.4049/jimmunol.172.11.6692

104. Pisetsky DS. The expression of HMGB1 on microparticles released during cell activation and cell death in vitro and in vivo. Mol Med. (2014) 20:158-63. doi: 10.2119/molmed.2014.00014

105. Reich CF III, Pisetsky DS. The content of DNA and RNA in microparticles released by Jurkat and HL-60 cells undergoing in vitro apoptosis. Exp Cell Res. (2009) 315:760-8. doi: 10.1016/j.yexcr.2008.12.014

106. Mause SF, Weber C. Microparticles: protagonists of a novel communication network for intercellular information exchange. Circ Res. (2010) 107:104757. doi: 10.1161/CIRCRESAHA.110.226456

107. Owens AP III, Mackman N. Microparticles in hemostasis and thrombosis. Circ Res. (2011) 108:1284-97. doi: 10.1161/CIRCRESAHA.110.233056

108. Nomura S, Ozaki Y, Ikeda Y. Function and role of microparticles in various clinical settings. Thromb Res. (2008) 123:8-23. doi: 10.1016/j.thromres.2008.06.006

109. Vasina E, Heemskerk JW, Weber C, Koenen RR. Platelets and plateletderived microparticles in vascular inflammatory disease. Inflamm Allergy Drug Targets. (2010) 9:346-54. doi: 10.2174/187152810793938008

110. Ullal AJ, Reich CF III, Clowse M, Criscione-Schreiber LG, Tochacek M, Monestier M, et al. Microparticles as antigenic targets of antibodies to DNA and nucleosomes in systemic lupus erythematosus. J Autoimmun. (2011) 36:173-80. doi: 10.1016/j.jaut.2011.02.001

111. Nielsen CT, Ostergaard O, Stener L, Iversen LV, Truedsson L, Gullstrand B, et al. Increased IgG on cell-derived plasma microparticles in systemic lupus erythematosus is associated with autoantibodies and complement activation. Arthritis Rheum. (2012) 64:1227-36. doi: 10.1002/art.34381

112. Mobarrez F, Vikerfors A, Gustafsson JT, Gunnarsson I, Zickert A, Larsson A, et al. Microparticles in the blood of patients with systemic lupus erythematosus. (SLE): phenotypic characterization and clinical associations. Sci Rep. (2016) 6:36025. doi: 10.1038/srep36025

113. Dieker J, Tel J, Pieterse E, Thielen A, Rother N, Bakker M, et al. Circulating apoptotic microparticles in systemic lupus erythematosus patients drive the activation of dendritic cell subsets and prime neutrophils 
for NETosis. Arthritis Rheumatol. (2016) 68:462-72. doi: 10.1002/ art.39417

114. Winberg LK, Jacobsen S, Nielsen CH. Microparticles from patients with systemic lupus erythematosus induce production of reactive oxygen species and degranulation of polymorphonuclear leukocytes. Arthritis Res Ther. (2017) 19:230. doi: 10.1186/s13075-017-1437-3

115. Di Domizio J, Dorta-Estremera S, Gagea M, Ganguly D, Meller S, Li P, et al. Nucleic acid-containing amyloid fibrils potently induce type I interferon and stimulate systemic autoimmunity. Proc Natl Acad Sci USA. (2012) 109:14550-5. doi: 10.1073/pnas.1206923109

116. Gallo PM, Rapsinski GJ, Wilson RP, Oppong GO, Sriram U, Goulian M, et al. Amyloid-DNA composites of bacterial biofilms stimulate autoimmunity. Immunity. (2015) 42:1171-84. doi: 10.1016/j.immuni.2015.06.002

117. Vieira SM, Pagovich OE, Kriegel MA. Diet, microbiota and autoimmune diseases. Lupus. (2014) 23:518-26. doi: 10.1177/0961203313501401

118. Crowl JT, Gray EE, Pestal K, Volkman HE, Stetson DB. Intracellular nucleic acid detection in autoimmunity. Annu Rev Immunol. (2017) 35:313-36. doi: 10.1146/annurev-immunol-051116-052331

119. Keyel PA. Dnases in health and disease. Dev Biol. (2017) 429:1-11. doi: 10.1016/j.ydbio.2017.06.028

120. Lee-Kirsch MA, Gong M, Chowdhury D, Senenko L, Engel K, Lee YA, et al. Mutations in the gene encoding the 3'-5' DNA exonuclease TREX1 are associated with systemic lupus erythematosus. Nat Genet. (2007) 39:1065-7. doi: $10.1038 /$ ng2091

121. Stetson DB, Ko JS, Heidmann T, Medzhitov R. Trexl prevents cell-intrinsic initiation of autoimmunity. Cell. (2008) 134:587-98. doi: 10.1016/j.cell.2008.06.032

122. Crow YJ, Manel N. Aicardi-Goutieres syndrome and the type I interferonopathies. Nat Rev Immunol. (2015) 15:429-40. doi: $10.1038 /$ nri3850

123. Cuadrado E, Vanderver A, Brown KJ, Sandza A, Takanohashi A, Jansen $\mathrm{MH}$, et al. Aicardi-Goutieres syndrome harbours abundant systemic and brain-reactive autoantibodies. Ann Rheum Dis. (2015) 74:1931-9. doi: 10.1136/annrheumdis-2014-205396

124. Ramantani G, Kohlhase J, Hertzberg C, Innes AM, Engel K, Hunger $\mathrm{S}$, et al. Expanding the phenotypic spectrum of lupus erythematosus in Aicardi-Goutieres syndrome. Arthritis Rheum. (2010) 62:1469-77. doi: $10.1002 /$ art.27367

125. Morita M, Stamp G, Robins P, Dulic A, Rosewell I, Hrivnak G, et al. Gene-targeted mice lacking the Trex1. (DNase III) 3'-> 5' DNA exonuclease develop inflammatory myocarditis. Mol Cell Biol. (2004) 24:6719-27. doi: 10.1128/MCB.24.15.6719-6727.2004

126. Gall A, Treuting P, Elkon KB, Loo YM, Gale M Jr, Barber GN, et al. Autoimmunity initiates in nonhematopoietic cells and progresses via lymphocytes in an interferon-dependent autoimmune disease. Immunity. (2012) 36:120-31. doi: 10.1016/j.immuni.2011.11.018

127. Okabe Y, Kawane K, Akira S, Taniguchi T, Nagata S. Toll-like receptorindependent gene induction program activated by mammalian DNA escaped from apoptotic DNA degradation. J Exp Med. (2005) 202:1333-9. doi: $10.1084 /$ jem.20051654

128. Yoshida H, Okabe Y, Kawane K, Fukuyama H, Nagata S. Lethal anemia caused by interferon-beta produced in mouse embryos carrying undigested DNA. Nat Immunol. (2005) 6:49-56. doi: 10.1038/ni1146

129. Shin HD, Park BL, Cheong HS, Lee HS, Jun JB, Bae SC. DNase II polymorphisms associated with risk of renal disorder among systemic lupus erythematosus patients. J Hum Genet. (2005) 50:107-11. doi: 10.1007/s10038-004-0227-3

130. Rodero MP, Tesser A, Bartok E, Rice GI, Della Mina E, Depp M, et al. Type I interferon-mediated autoinflammation due to DNase II deficiency. Nat Commun. (2017) 8:2176. doi: 10.1038/s41467-01701932-3

131. Gao D, Li T, Li XD, Chen X, Li QZ, Wight-Carter M, et al. Activation of cyclic GMP-AMP synthase by self-DNA causes autoimmune diseases. Proc Natl Acad Sci USA. (2015) 112:E5699-705. doi: 10.1073/pnas.1516465112

132. Gavin AL, Huang D, Huber C, Martensson A, Tardif V, Skog PD, et al. PLD3 and PLD4 are single-stranded acid exonucleases that regulate endosomal nucleic-acid sensing. Nat Immunol. (2018) 19:942-53. doi: 10.1038/s41590-018-0179-y
133. Okada Y, Terao C, Ikari K, Kochi Y, Ohmura K, Suzuki A, et al. Meta-analysis identifies nine new loci associated with rheumatoid arthritis in the Japanese population. Nat Genet. (2012) 44:511-6. doi: 10.1038/ng.2231

134. Terao C, Ohmura K, Kawaguchi Y, Nishimoto T, Kawasaki A, Takehara K, et al. PLD4 as a novel susceptibility gene for systemic sclerosis in a Japanese population. Arthritis Rheum. (2013) 65:472-80. doi: 10.1002/art.37777

135. Napirei M, Ricken A, Eulitz D, Knoop H, Mannherz HG. Expression pattern of the deoxyribonuclease 1 gene: lessons from the Dnase1 knockout mouse. Biochem J. (2004) 380:929-37. doi: 10.1042/bj20040046

136. Bygrave AE, Rose KL, Cortes-Hernandez J, Warren J, Rigby RJ, Cook HT, et al. Spontaneous autoimmunity in 129 and C57BL/6 mice-implications for autoimmunity described in gene-targeted mice. PLoS Biol. (2004) 2:E243. doi: 10.1371/journal.pbio.0020243

137. Yasutomo K, Horiuchi T, Kagami S, Tsukamoto H, Hashimura C, Urushihara $\mathrm{M}$, et al. Mutation of DNASE1 in people with systemic lupus erythematosus. Nat Genet. (2001) 28:313-4. doi: 10.1038/91070

138. Chakraborty P, Hadj Kacem H, Makni-Karray K, Jarraya F, Hachicha J, Ayadi $\mathrm{H}$. The A/T mutation in exon 2 of the DNASE1 gene is not present in Tunisian patients with systemic lupus erythematosus or in healthy subjects. Arthritis Rheum. (2003) 48:3297-8. doi: 10.1002/art.11318

139. Sallai K, Nagy E, Derfalvy B, Muzes G, Gergely P. Antinucleosome antibodies and decreased deoxyribonuclease activity in sera of patients with systemic lupus erythematosus. Clin Diagn Lab Immunol. (2005) 12:56-9. doi: 10.1128/CDLI.12.1.56-59.2005

140. Napirei M, Karsunky H, Zevnik B, Stephan H, Mannherz HG, Moroy T. Features of systemic lupus erythematosus in Dnase1-deficient mice. Nat Genet. (2000) 25:177-81. doi: 10.1038/76032

141. Zykova SN, Tveita AA, Rekvig OP. Renal Dnase1 enzyme activity and protein expression is selectively shut down in murine and human membranoproliferative lupus nephritis. PLOS ONE. (2010) 5:12096. doi: 10.1371/journal.pone.0012096

142. Pedersen HL, Horvei KD, Thiyagarajan D, Norby GE, Seredkina N, Moroni $\mathrm{G}$, et al. Lupus nephritis: low urinary DNase I levels reflect loss of renal DNase I and may be utilized as a biomarker of disease progression.J Pathol Clin Res. (2018). doi: 10.1002/cjp2.99

143. Koizumi T. Genetic control of urinary deoxyribonuclease I. (DNase I) activity levels in mice. Exp Anim. (1996) 45:245-50. doi: 10.1538/expanim. 45.245

144. Cheng THT, Lui KO, Peng XL, Cheng SH, Jiang P, Chan KCA, et al. DNase1 does not appear to play a major role in the fragmentation of plasma DNA in a knockout mouse model. Clin Chem. (2018) 64:406-8. doi: 10.1373/clinchem.2017.280446

145. Napirei M, Ludwig S, Mezrhab J, Klockl T, Mannherz HG. Murine serum nucleases-contrasting effects of plasmin and heparin on the activities of DNase1 and DNase1-like 3. (DNase1l3). FEBS J. (2009) 276:1059-73. doi: 10.1111/j.1742-4658.2008.06849.x

146. Shiokawa D, Tanuma S. Characterization of human DNase I family endonucleases and activation of DNase gamma during apoptosis. Biochemistry. (2001) 40:143-52. doi: 10.1021/bi001041a

147. Wilber A, Lu M, Schneider MC. Deoxyribonuclease I-like III is an inducible macrophage barrier to liposomal transfection. Mol Ther. (2002) 6:35-42. doi: $10.1006 / \mathrm{mthe} .2002 .0625$

148. Al-Mayouf SM, Sunker A, Abdwani R, Abrawi SA, Almurshedi F, Alhashmi N, et al. Loss-of-function variant in DNASE1L3 causes a familial form of systemic lupus erythematosus. Nat Genet. (2011) 43:1186-8. doi: $10.1038 /$ ng.975

149. Ozcakar ZB, Foster J II, Diaz-Horta O, Kasapcopur O, Fan YS, Yalcinkaya F, et al. DNASE1L3 mutations in hypocomplementemic urticarial vasculitis syndrome. Arthritis Rheum. (2013) 65:2183-9. doi: 10.1002/ar t. 38010

150. Carbonella A, Mancano G, Gremese E, Alkuraya FS, Patel N, Gurrieri F, et al. An autosomal recessive DNASE1L3-related autoimmune disease with unusual clinical presentation mimicking systemic lupus erythematosus. Lupus. (2017) 26:768-72. doi: 10.1177/096120331 6676382

151. Ueki M, Takeshita H, Fujihara J, Iida R, Yuasa I, Kato H, et al. Caucasianspecific allele in non-synonymous single nucleotide polymorphisms of the gene encoding deoxyribonuclease I-like 3, potentially relevant to 
autoimmunity, produces an inactive enzyme. Clin Chim Acta. (2009) 407:204. doi: 10.1016/j.cca.2009.06.022

152. Mayes MD, Bossini-Castillo L, Gorlova O, Martin JE, Zhou X, Chen WV, et al. Immunochip analysis identifies multiple susceptibility loci for systemic sclerosis. Am J Hum Genet. (2014) 94:47-61. doi: 10.1016/j.ajhg.2013.12.002

153. Zochling J, Newell F, Charlesworth JC, Leo P, Stankovich J, Cortes A, et al. An Immunochip-based interrogation of scleroderma susceptibility variants identifies a novel association at DNASE1L3. Arthritis Res Ther. (2014) 16:438. doi: 10.1186/s13075-014-0438-8

154. Weisenburger T, Von Neubeck B, Schneider A, Ebert N, Schreyer D, Acs A, et al. Epistatic interactions between mutations of deoxyribonuclease 1Like 3 and the inhibitory Fc Gamma receptor IIB result in very early and massive autoantibodies against double-stranded DNA. Front Immunol. (2018) 9:1551. doi: 10.3389/fimmu.2018.01551

155. Barrat FJ, Meeker T, Gregorio J, Chan JH, Uematsu S, Akira S, et al. Nucleic acids of mammalian origin can act as endogenous ligands for Toll-like receptors and may promote systemic lupus erythematosus. J Exp Med. (2005) 202:1131-9. doi: 10.1084/jem.20050914

156. Lau CM, Broughton C, Tabor AS, Akira S, Flavell RA, Mamula MJ, et al. RNA-associated autoantigens activate B cells by combined B cell antigen receptor/Toll-like receptor 7 engagement. J Exp Med. (2005) 202:1171-7. doi: $10.1084 /$ jem. 20050630

157. Majer O, Liu B, Barton GM. Nucleic acid-sensing TLRs: trafficking and regulation. Curr Opin Immunol. (2017) 44:26-33. doi: 10.1016/j.coi.2016.10.003

158. Christensen SR, Shlomchik MJ. Regulation of lupus-related autoantibody production and clinical disease by Toll-like receptors. Semin Immunol. (2007) 19:11-23. doi: 10.1016/j.smim.2006.12.005

159. Sharma S, Fitzgerald KA, Cancro MP, Marshak-Rothstein A. Nucleic acidsensing receptors: rheostats of autoimmunity and autoinflammation. $J$ Immunol. (2015) 195:3507-12. doi: 10.4049/jimmunol.1500964

160. Ahn J, Gutman D, Saijo S, Barber GN. STING manifests self DNAdependent inflammatory disease. Proc Natl Acad Sci USA. (2012) 109:1938691. doi: 10.1073/pnas.1215006109

161. Baum R, Sharma S, Carpenter S, Li QZ, Busto P, Fitzgerald KA, et al. Cutting edge: AIM2 and endosomal TLRs differentially regulate arthritis and autoantibody production in DNase II-deficient mice. J Immunol. (2015) 194:873-7. doi: 10.4049/jimmunol.1402573

162. Okabe Y, Kawane K, Nagata S. IFN regulatory factor. (IRF) 3/7-dependent and -independent gene induction by mammalian DNA that escapes degradation. Eur J Immunol. (2008) 38:3150-8. doi: 10.1002/eji.200838559

163. Pawaria S, Moody K, Busto P, Nundel K, Choi CH, Ghayur T, et al. Cutting Edge: DNase II deficiency prevents activation of autoreactive B cells by double-stranded DNA endogenous ligands. J Immunol. (2015) 194:1403-7. doi: 10.4049/jimmunol.1402893

164. Baum R, Nundel K, Pawaria S, Sharma S, Busto P, Fitzgerald KA, et al. Synergy between hematopoietic and radioresistant stromal cells is required for autoimmune manifestations of DNase $\mathrm{II}^{-/-} \mathrm{IFNaR}^{-/}$mice. J Immunol. (2016) 196:1348-54. doi: 10.4049/jimmunol.1502130

165. Jeremiah N, Neven B, Gentili M, Callebaut I, Maschalidi S, Stolzenberg MC, et al. Inherited STING-activating mutation underlies a familial inflammatory syndrome with lupus-like manifestations. J Clin Invest. (2014) 124:5516-20. doi: 10.1172/JCI79100

166. Liu Y, Jesus AA, Marrero B, Yang D, Ramsey SE, Sanchez G, et al. Activated STING in a vascular and pulmonary syndrome. N Engl J Med. (2014) 371:507-18. doi: 10.1056/NEJMoa1312625

167. Sharma S, Campbell AM, Chan J, Schattgen SA, Orlowski GM, Nayar R, et al. Suppression of systemic autoimmunity by the innate immune adaptor STING. Proc Natl Acad Sci USA. (2015) 112:E710-7. doi: $10.1073 /$ pnas. 1420217112

168. Marshak-Rothstein A, Rifkin IR. Immunologically active autoantigens: the role of toll-like receptors in the development of chronic inflammatory disease. Annu Rev Immunol. (2007) 25:419-41. doi: 10.1146/annurev.immunol.22.012703.104514

169. Ehlers M, Fukuyama H, Mcgaha TL, Aderem A, Ravetch JV. TLR9/MyD88 signaling is required for class switching to pathogenic IgG2a and 2b autoantibodies in SLE. J Exp Med. (2006) 203:553-61. doi: $10.1084 /$ jem. 20052438
170. Komatsuda A, Wakui H, Iwamoto K, Ozawa M, Togashi M, Masai R, et al. Up-regulated expression of Toll-like receptors mRNAs in peripheral blood mononuclear cells from patients with systemic lupus erythematosus. Clin Exp Immunol. (2008) 152:482-7. doi: 10.1111/j.1365-2249.2008.03646.x

171. Tian J, Avalos AM, Mao SY, Chen B, Senthil K, Wu H, et al. Toll-like receptor 9-dependent activation by DNA-containing immune complexes is mediated by HMGB1 and RAGE. Nat Immunol. (2007) 8:487-96. doi: 10.1038/ni1457

172. Wen Z, Xu L, Chen X, Xu W, Yin Z, Gao X, et al. Autoantibody induction by DNA-containing immune complexes requires HMGB1 with the TLR2/microRNA-155 pathway. J Immunol. (2013) 190:5411-22. doi: 10.4049/jimmunol.1203301

173. Celhar T, Magalhaes R, Fairhurst AM. TLR7 and TLR9 in SLE: when sensing self goes wrong. Immunol Res. (2012) 53:58-77. doi: $10.1007 /$ s12026-012-8270-1

174. Fernandez-Castro M, Mellor-Pita S, Citores MJ, Munoz P, Tutor-Ureta P, Silva L, et al. Common variable immunodeficiency in systemic lupus erythematosus. Semin Arthritis Rheum. (2007) 36:238-45. doi: 10.1016/j.semarthrit.2006.09.005

175. Visentini M, Conti V, Cagliuso M, Tinti F, Siciliano G, Trombetta AC, et al. Regression of systemic lupus erythematosus after development of an acquired toll-like receptor signaling defect and antibody deficiency. Arthritis Rheum. (2009) 60:2767-71. doi: 10.1002/art.24760

176. Christensen SR, Shupe J, Nickerson K, Kashgarian M, Flavell RA, Shlomchik MJ. Toll-like receptor 7 and TLR9 dictate autoantibody specificity and have opposing inflammatory and regulatory roles in a murine model of lupus. Immunity. (2006) 25:417-28. doi: 10.1016/j.immuni.200 6.07 .013

177. Jackson SW, Scharping NE, Kolhatkar NS, Khim S, Schwartz MA, Li QZ, et al. Opposing impact of B cell-intrinsic TLR7 and TLR9 signals on autoantibody repertoire and systemic inflammation. J Immunol. (2014) 192:4525-32. doi: 10.4049/jimmunol.1400098

178. Soni C, Wong EB, Domeier PP, Khan TN, Satoh T, Akira S, et al. B cell-intrinsic TLR7 signaling is essential for the development of spontaneous germinal centers. J Immunol. (2014) 193:4400-14. doi: 10.4049/jimmunol.1401720

179. Wong EB, Khan TN, Mohan C, Rahman ZS. The lupus-prone NZM2410/NZW strain-derived Sle1b sublocus alters the germinal center checkpoint in female mice in a B cell-intrinsic manner. J Immunol. (2012) 189:5667-81. doi: 10.4049/jimmunol.1201661

180. Schell SL, Soni C, Fasnacht MJ, Domeier PP, Cooper TK, Rahman ZSM. Mer receptor tyrosine kinase signaling prevents self-ligand sensing and aberrant selection in germinal centers. J Immunol. (2017) 199:4001-15. doi: 10.4049/jimmunol.1700611

181. Nickerson KM, Christensen SR, Shupe J, Kashgarian M, Kim D, Elkon $\mathrm{K}$, et al. TLR9 regulates TLR7- and MyD88-dependent autoantibody production and disease in a murine model of lupus. J Immunol. (2010) 184:1840-8. doi: 10.4049/jimmunol.0902592

182. Pisitkun P, Deane JA, Difilippantonio MJ, Tarasenko T, Satterthwaite $\mathrm{AB}$, Bolland S. Autoreactive $\mathrm{B}$ cell responses to RNA-related antigens due to TLR7 gene duplication. Science. (2006) 312:1669-72. doi: $10.1126 /$ science. 1124978

183. Yu P, Wellmann U, Kunder S, Quintanilla-Martinez L, Jennen L, Dear N, et al. Toll-like receptor 9-independent aggravation of glomerulonephritis in a novel model of SLE. Int Immunol. (2006) 18:1211-9. doi: 10.1093/intimm/dxl067

184. Nickerson KM, Wang Y, Bastacky S, Shlomchik MJ. Toll-like receptor 9 suppresses lupus disease in Fas-sufficient MRL Mice. PLoS ONE. (2017) 12:e0173471. doi: 10.1371/journal.pone.0173471

185. Bossaller L, Christ A, Pelka K, Nundel K, Chiang PI, Pang C, et al. TLR9 deficiency leads to accelerated renal disease and myeloid lineage abnormalities in pristane-induced murine lupus. J Immunol. (2016) 197:1044-53. doi: 10.4049/jimmunol.1501943

186. Stoehr AD, Schoen CT, Mertes MM, Eiglmeier S, Holecska V, Lorenz AK, et al. TLR9 in peritoneal B-1b cells is essential for production of protective self-reactive IgM to control Th17 cells and severe autoimmunity. J Immunol. (2011) 187:2953-65. doi: 10.4049/jimmunol.1003340

187. Shinde R, Hezaveh K, Halaby MJ, Kloetgen A, Chakravarthy A, Da Silva Medina $T$, et al. Apoptotic cell-induced AhR activity is 
required for immunological tolerance and suppression of systemic lupus erythematosus in mice and humans. Nat Immunol. (2018) 19:571-82. doi: 10.1038/s41590-018-0107-1

188. Bianchi ME. HMGB1 loves company. J Leukoc Biol. (2009) 86:573-6. doi: $10.1189 / \mathrm{jlb} .1008585$

189. Lartigue A, Colliou N, Calbo S, Francois A, Jacquot S, Arnoult C, et al. Critical role of TLR2 and TLR4 in autoantibody production and glomerulonephritis in lpr mutation-induced mouse lupus. J Immunol. (2009) 183:6207-16. doi: 10.4049/jimmunol.0803219

190. Urbonaviciute V, Starke C, Pirschel W, Pohle S, Frey S, Daniel C, et al. Tolllike receptor 2 is required for autoantibody production and development of renal disease in pristane-induced lupus. Arthritis Rheum. (2013) 65:1612-23. doi: 10.1002/art.37914

191. Volkman HE, Stetson DB. The enemy within: endogenous retroelements and autoimmune disease. Nat Immunol. (2014) 15:415-22. doi: 10.1038/ni.2872

192. Crow MK. Type I interferon in the pathogenesis of lupus. J Immunol. (2014) 192:5459-68. doi: 10.4049/jimmunol.1002795

193. Muskardin TLW, Niewold TB. Type I interferon in rheumatic diseases. Nat Rev Rheumatol. (2018) 14:214-28. doi: 10.1038/nrrheum.2018.31

194. Rice GI, Del Toro Duany Y, Jenkinson EM, Forte GM, Anderson BH, Ariaudo G, et al. Gain-of-function mutations in IFIH1 cause a spectrum of human disease phenotypes associated with upregulated type I interferon signaling. Nat Genet. (2014) 46:503-9. doi: 10.1038/ng.2933

195. Della Mina E, Rodero MP, Crow YJ. Polymorphisms in IFIH1: the good and the bad. Nat Immunol. (2017) 18:708-9. doi: 10.1038/ni.3765

196. Crow YJ. Type I interferonopathies: mendelian type I interferon up-regulation. Curr Opin Immunol. (2015) 32:7-12. doi: 10.1016/j.coi.2014.10.005

197. Salloum R, Niewold TB. Interferon regulatory factors in human lupus pathogenesis. Transl Res. (2011) 157:326-31. doi: 10.1016/j.trsl.2011.01.006

198. Kaufman KM, Zhao J, Kelly JA, Hughes T, Adler A, Sanchez E, et al. Fine mapping of Xq28: both MECP2 and IRAK1 contribute to risk for systemic lupus erythematosus in multiple ancestral groups. Ann Rheum Dis. (2013) 72:437-44. doi: 10.1136/annrheumdis-2012-201851

199. Salloum R, Franek BS, Kariuki SN, Rhee L, Mikolaitis RA, Jolly M, et al. Genetic variation at the IRF7/PHRF1 locus is associated with autoantibody profile and serum interferon-alpha activity in lupus patients. Arthritis Rheum. (2010) 62:553-61. doi: 10.1002/art.27182

200. Niewold TB, Kelly JA, Kariuki SN, Franek BS, Kumar AA, Kaufman KM, et al. IRF5 haplotypes demonstrate diverse serological associations which predict serum interferon alpha activity and explain the majority of the genetic association with systemic lupus erythematosus. Ann Rheum Dis. (2012) 71:463-8. doi: 10.1136/annrheumdis-2011-200463

201. Chrabot BS, Kariuki SN, Zervou MI, Feng X, Arrington J, Jolly M, et al. Genetic variation near IRF8 is associated with serologic and cytokine profiles in systemic lupus erythematosus and multiple sclerosis. Genes Immun. (2013) 14:471-8. doi: 10.1038/gene.2013.42

202. Liu Z, Davidson A. IFN $\alpha$ inducible models of murine SLE. Front Immunol. (2013) 4:306. doi: 10.3389/fimmu.2013.00306

203. Domeier PP, Chodisetti SB, Schell SL, Kawasawa YI, Fasnacht MJ, Soni C, et al. B-cell-intrinsic type 1 interferon signaling is crucial for loss of tolerance and the development of autoreactive B cells. Cell Rep. (2018) 24:406-18. doi: 10.1016/j.celrep.2018.06.046
204. Jackson SW, Jacobs HM, Arkatkar T, Dam EM, Scharping NE, Kolhatkar NS, et al. B cell IFN $\beta$ receptor signaling promotes autoimmune germinal centers via cell-intrinsic induction of BCL-6. J Exp Med. (2016) 213:733-50. doi: $10.1084 /$ jem.20151724

205. Nickerson KM, Cullen JL, Kashgarian M, Shlomchik MJ. Exacerbated autoimmunity in the absence of TLR9 in MRL.Fas(lpr) mice depends on Ifnar1. J Immunol. (2013) 190:3889-94. doi: 10.4049/jimmunol.1203525

206. Pollard KM, Cauvi DM, Toomey CB, Morris KV, Kono DH. Interferon- $\gamma$ and systemic autoimmunity. Discov Med. (2013) 16:123-31.

207. Munroe ME, Lu R, Zhao YD, Fife DA, Robertson JM, Guthridge JM, et al. Altered type II interferon precedes autoantibody accrual and elevated type I interferon activity prior to systemic lupus erythematosus classification. Ann Rheum Dis. (2016) 75:2014-21. doi: 10.1136/annrheumdis-2015208140

208. Domeier PP, Chodisetti SB, Soni C, Schell SL, Elias MJ, Wong EB, et al. IFN- $\gamma$ receptor and STAT1 signaling in B cells are central to spontaneous germinal center formation and autoimmunity. J Exp Med. (2016) 213:71532. doi: $10.1084 /$ jem. 20151722

209. Rubtsova K, Rubtsov AV, Cancro MP, Marrack P. Age-associated B cells: A T-bet-dependent effector with roles in protective and pathogenic immunity. J Immunol. (2015) 195:1933-7. doi: 10.4049/jimmunol.1501209

210. Balomenos D, Rumold R, Theofilopoulos AN. Interferon-gamma is required for lupus-like disease and lymphoaccumulation in MRL-lpr mice. J Clin Invest. (1998) 101:364-71. doi: 10.1172/JCI750

211. Harigai M, Kawamoto M, Hara M, Kubota T, Kamatani N, Miyasaka $\mathrm{N}$. Excessive production of IFN-gamma in patients with systemic lupus erythematosus and its contribution to induction of B lymphocyte stimulator/B cell-activating factor/TNF ligand superfamily-13B. J Immunol. (2008) 181:2211-9. doi: 10.4049/jimmunol.181.3.2211

212. Lee SK, Silva DG, Martin JL, Pratama A, Hu X, Chang PP, et al. Interferon- $\gamma$ excess leads to pathogenic accumulation of follicular helper $\mathrm{T}$ cells and germinal centers. Immunity. (2012) 37:880-92. doi: 10.1016/j.immuni.2012.10.010

213. Hertzog P, Forster S, Samarajiwa S. Systems biology of interferon responses. J Interferon Cytokine Res. (2011) 31:5-11. doi: 10.1089/jir. 2010.0126

214. Hall JC, Casciola-Rosen L, Berger AE, Kapsogeorgou EK, Cheadle C, Tzioufas AG, et al. Precise probes of type II interferon activity define the origin of interferon signatures in target tissues in rheumatic diseases. Proc Natl Acad Sci USA. (2012) 109:17609-14. doi: 10.1073/pnas.1209 724109

Conflict of Interest Statement: The authors declare that the research was conducted in the absence of any commercial or financial relationships that could be construed as a potential conflict of interest.

Copyright $(02019$ Soni and Reizis. This is an open-access article distributed under the terms of the Creative Commons Attribution License (CC BY). The use, distribution or reproduction in other forums is permitted, provided the original author(s) and the copyright owner(s) are credited and that the original publication in this journal is cited, in accordance with accepted academic practice. No use, distribution or reproduction is permitted which does not comply with these terms. 